\title{
Deciphering groundwater quality for irrigation and domestic purposes - a case study in Suri I and II blocks, Birbhum District, West Bengal, India
}

\author{
SHREYA DAS and S K NAG* \\ Department of Geological Sciences, Jadavpur University, Kolkata 700 032, India. \\ *Corresponding author.e-mail:nag_sk@yahoo.com
}

Assessment of the hydrochemical characteristics of water and aquifer hydraulic properties is important for groundwater planning and management in the study area. It is not only the basic need for human existence but also a vital input for all development activities. The present hydro-geochemical study of groundwater samples from the Suri I and II blocks of Birbhum district, West Bengal $\left(23.76^{\circ}-23.99^{\circ} \mathrm{N}\right.$; $87.42^{\circ}-87.64^{\circ} \mathrm{E}$ ) was carried out to assess their suitability for agricultural, domestic and drinking purposes. For this study, samples were collected from 26 locations during the post-monsoon and pre-monsoon sessions spanning over 2012 and 2013. Groundwater samples were analyzed for their physical and chemical properties using standard laboratory methods.

Physical and chemical parameters of groundwater such as $\mathrm{pH}$, electrical conductivity, total dissolved solids, $\mathrm{Na}, \mathrm{K}, \mathrm{Ca}, \mathrm{Mg}, \mathrm{Fe}, \mathrm{Cl}, \mathrm{HCO}_{3}, \mathrm{SO}_{4}$ and $\mathrm{F}$ were determined. Various water quality indices like SAR, SSP, PI, RSC, MAR and KR have been calculated for each water sample to identify the irrigational suitability standard. According to most of these parameters, the groundwater has been found to be well to moderately suitable for irrigation. In the post-monsoon session exceptionally high RSC values for around $80 \%$ samples indicate an alkaline hazard to the soil. The ion balance histogram for post-monsoon indicates undesirable ion balance values according to fresh water standards whereas in pre-monsoon, the samples show good ion balance in water. For determination of the drinking suitability standard of groundwater, three parameters have been considered - total hardness (TH), Piper's trilinear diagram and water quality index study. Groundwater of the present study area has been found to be moderately-hard to hard during both sampling sessions and hence poses no health risk which could arise due to excess consumption of calcium or magnesium. Hydrogeochemical facies in the form of Piper's trilinear diagram plot which helps in identification of the water 'type' which can render a particular taste or odour to water, indicates that groundwater in the study area is majorly of $\mathrm{CaMgHCO}_{3}$ and $\mathrm{NaHCO}_{3}$ type (fresh type) during both post-monsoon and pre-monsoon sessions barring a couple of samples which are of $\mathrm{CaMgSO}_{4} / \mathrm{CaMgClSO}_{4}$ type in pre-monsoon. Water quality index study reveals that close to $90 \%$ of the water samples are suitable for drinking during post-monsoon compared to pre-monsoon during which period only $60 \%$ of water samples fall under the suitable drinking water category.

Gibbs' diagrams, which help in identification of natural processes controlling hydrogeochemistry of groundwater indicates that for both post-monsoon and pre-monsoon sessions, the overall hydrogeochemistry of the study area is dominated by rock-water interaction processes.

Keywords. Groundwater quality; irrigation and domestic suitability; ionic balance, Suri I and II blocks; Birbhum District. 


\section{Introduction}

The competition for water resources has gained importance in recent years, not only in India but also in many places of the world. Groundwater is the purest form of water sourced from natural resources and meets the overall demand of rural and semi-urban people. But the development of human societies and industry result in bioenvironmental problems; pollution puts the water, air and soil resources at risk (Milovanovic 2007). Groundwater has become the major source of water supply for domestic, industrial and agricultural sectors of many countries. In recent years, many cities of developing countries are experiencing rapid demographic growth due to rural exodus. Urbanization and the unregulated growth of the population have altered the local topography and drainage system which directly affect both quality and quantity of the groundwater (Vasanthavigar et al. 2010). Inadequate environmental protection measures in coal mining, waste dumps, thermal power plants, steel plants, sugar factories, fertilizer production units and cement plants have resulted in significant water pollution (Chatterjee et al. 2010). Groundwater quality depends on the quality of recharged water, atmospheric precipitation, inland surface water and subsurface geochemical processes. Temporal changes in the origin and constitution of the recharged water, hydrological and human factors frequently cause periodic changes in groundwater quality (Sreedevi 2004; Milovanovic 2007; Aghazadeh and Mogaddam 2010). Many research publications have come out on evaluation for domestic and industrial activities and related groundwater quality monitoring (Rivers et al. 1996; Al-Futaisi et al. 2007; Jalali 2007; Pritchard et al. 2008; Srinivasamoorthy et al. 2008; Vasanthavigar et al. 2010; Nag and Ghosh 2013; Nag 2014).

Pollution of groundwater affects water quality, threatens human health and economic development owing to the suitability of water for various purposes (Subramani et al. 2005; Schiavo et al. 2006). In developing world, $80 \%$ of diseases are directly related to poor drinking water and unsanitary conditions (UNESCO 2007). Geochemical studies of groundwater provide a better understanding of possible changes in its quality as development progresses. Therefore, determination of groundwater quality is very important to observe the suitability of water for a particular use.

The aim of the study is to investigate the groundwater quality in the region since groundwater resources are widely used for drinking, agricultural and industrial purposes. It is important to ascertain the groundwater quality of the area for domestic and other uses. The objective of this paper is to use hydrochemical methods to assess the suitability of groundwater in the area for irrigation as well as domestic purposes.

\section{Study area}

The present study has been carried out in Suri (comprising of two blocks - Suri I and Suri II), the district headquarter of Birbhum district, West Bengal, India. The blocks are located between latitudes $23.76^{\circ}-23.99^{\circ} \mathrm{N}$ and longitudes $87.42^{\circ}-$ $87.64^{\circ} \mathrm{E}$ (figure 1). The climate of the area is generally dry. Summer temperatures soar to a maximum of $40^{\circ} \mathrm{C}$ or above whereas in winter, temperatures dip to around $10^{\circ} \mathrm{C}$. Majority of the rainfall is limited to the monsoon season from June-October and hovers around an average of $1100 \mathrm{~mm}$. The area is characterized by rural setting and main occupation of the people is agriculture. Water in the area is generally drawn from bore wells and dug wells, and the use of submersible pumps has seen a rise over the last few years for agricultural purposes.

The study area largely comprises of alternating layers of sand and clay, which are soft sediments and part of the Ganga-Kosi Formation. Granite gneiss which are hard and foliated type rocks belonging to the Chotanagpur Gneissic complex, constitute the north-western part of the study area. Hard clays dominate specific parts of the block in the eastern parts of Suri, whereas lateritic soils are scattered mainly in the upper parts of Suri.

\section{Methodology and data used}

Dry, clean and sterilized plastic bottles were used to get fresh aquifer water for sampling. Before collection, the bottles were well rinsed. For the present study, water samples from 26 borewells have been collected in December 2012 during the post-monsoon period and April 2013 during premonsoon period (figure 1). The collected samples were then stored in $500 \mathrm{ml}$ preconditioned highdensity polythene bottles and were carefully sealed with proper labelling. For all samples, temperature, $\mathrm{pH}$ and electrical conductivity (EC) were determined in the field with standard field equipment - Waterproof Tester Combo by Hanna Instruments. Samples were analyzed in the laboratory of Environmental Science Department of University of Burdwan, West Bengal. For quantitative chemical analysis of major ions in groundwater, standard analytical chemistry procedures, comprising titrimetry and spectrophotometry, were employed following American Public Health Association guidelines (APHA 1995). 

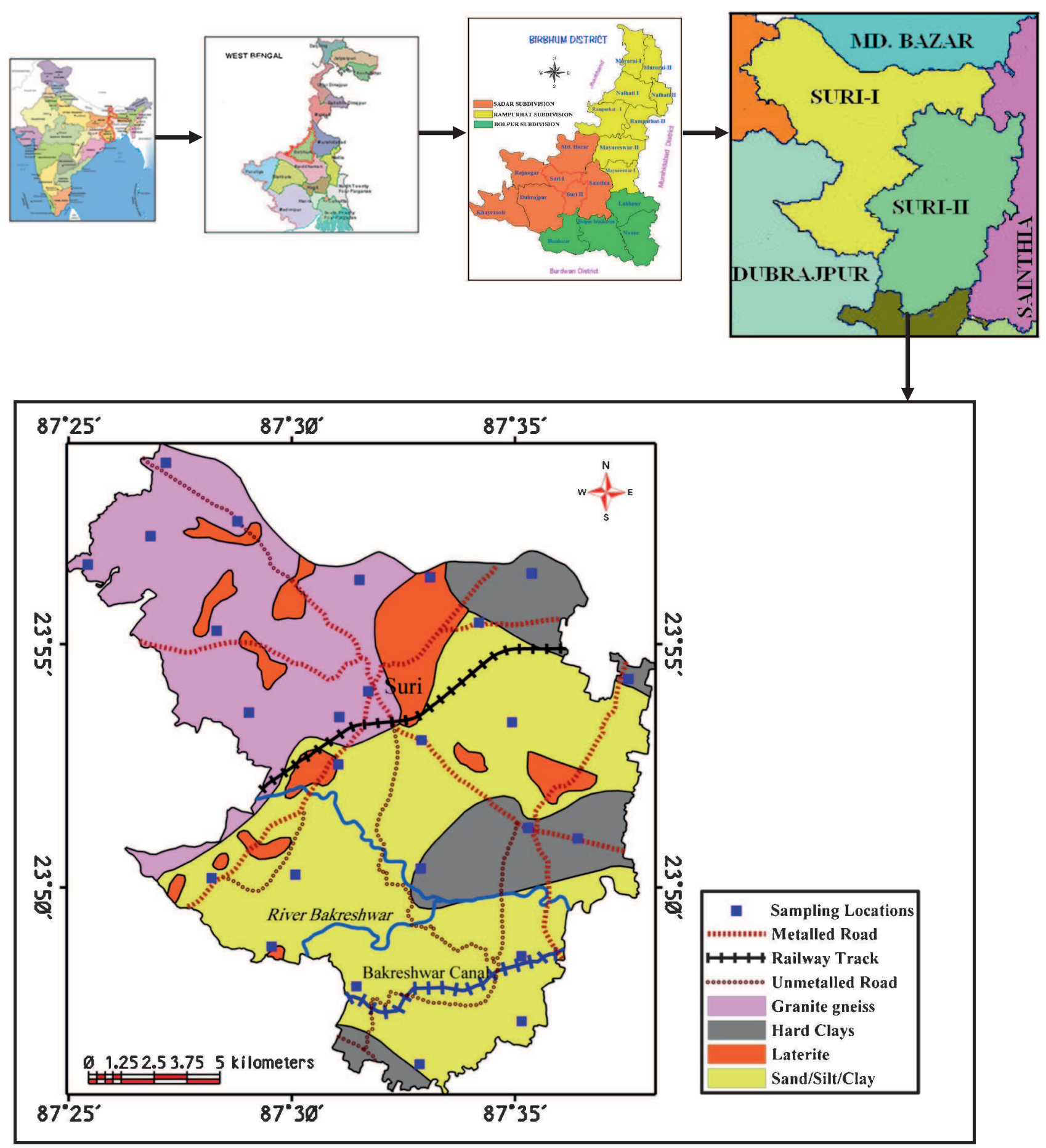

Figure 1. Map of the study area presenting the sampling location points and geology of the area.

To evaluate the suitability of the water quality for agricultural purposes, the parameters such as SAR and SSP (soluble Na\%), RSC, MAR, PI and KR were calculated using standard formulae mentioned in the text. The SAR values were plotted over the US salinity diagram against the EC values (log scale axis); SSP values were plotted over the Wilcox diagram against the EC values; the PI values were plotted over Doneen's chart against total ionic concentration; the spread of the RSC and MAR values have been represented in the form of spatial distribution maps for both sessions.

Besides total hardness results, the suitability of groundwater for drinking purposes has been determined by the use of hydrogeochemical facies (Piper trilinear diagram) (Piper 1944) and water quality index study (Tiwari and Mishra 1985). GIS software packages TNT Mips 2012 and Golden Software Surfer 7 have been used to map and analyse the data for the evaluation of groundwater data. 


\section{Results and discussion}

\subsection{Physico-chemical parameters of groundwater}

The $\mathrm{pH}$ values of the groundwater varies from 7.00 8.40 (in post-monsoon) with an average of 7.50, and 6.4-8.4 (in pre-monsoon) with an average of 7.1, which indicates that except for few samples, all other groundwater samples are alkaline in nature (figure $2 \mathrm{a}, \mathrm{b}$ ). The average concentration of Total Dissolved Solids (TDS) ranged from 244.3 (postmonsoon) to 249.0 (pre-monsoon) $\mathrm{mg} / \mathrm{L}$ in the study area (figure $3 \mathrm{a}, \mathrm{b}$ ). Normally TDS in water may originate from natural sources and sewage discharges. The electrical conductivity (EC) in the study area varies from 90.00 to 300.00 (in post-monsoon) and 150.00 to 1200.00 (in pre-monsoon) with an average of 212.7 (post-monsoon) and 556.2 (pre-monsoon) $\mu \mathrm{S} / \mathrm{cm}$ at $25^{\circ} \mathrm{C}$ (figure $4 \mathrm{a}, \mathrm{b}$ ). The total hardness (TH) of water is a measure of mainly calcium carbonate and magnesium carbonate dissolved in groundwater. The general acceptance level of hardness is $300 \mathrm{mg} / \mathrm{L}$, although WHO has set an allowable limit of $600 \mathrm{mg} / \mathrm{L}$. The total hardness in the study area ranges between 55 and $365 \mathrm{mg} / \mathrm{L}$ in post-monsoon while in pre-monsoon it ranges between 48 and 384 $\mathrm{mg} / \mathrm{L}$ (figure $5 \mathrm{a}, \mathrm{b}$ ).

Calcium concentration ranged from 12.6 to 109.2 $\mathrm{mg} / \mathrm{L}$ in post-monsoon and 6.7 to $95.8 \mathrm{mg} / \mathrm{L}$ in premonsoon periods (figure $6 \mathrm{a}, \mathrm{b}$ ). Acceptable limit of calcium in drinking water is $75 \mathrm{mg} / \mathrm{L}(200 \mathrm{mg} / \mathrm{L}$ in case of no other alternative source) (BIS 2012). Calcium ion is necessary for proper mineralization of bones and bone strength. Deficiency in intake of calcium leads to eventual demineralization of bones for complementing the inadequate amounts of calcium in the body.

Acceptable limit of magnesium in drinking water is $30 \mathrm{mg} / \mathrm{L}(100 \mathrm{mg} / \mathrm{L}$ in case of no other alternative source) (BIS 2012). Magnesium helps in maintaining normal nerve and muscle function, a healthy immune system and helps bones remain strong. It also helps in regulation of blood glucose levels and aid in the production of energy and protein. Deficiency of magnesium in the human diet might lead to anxiety, fatigue or anorexia. The magnesium concentration ranges between 3.2 and $42.5 \mathrm{mg} / \mathrm{L}$ in post-monsoon and $7.6-35.3 \mathrm{mg} / \mathrm{L}$ in pre-monsoon (figure 7a, b).

Iron is an essential element in the human body and is required physiologically on various aspects (Moore 1973). Although iron has little concern as a health hazard, it is still considered as a nuisance in excessive quantities (Dart 1974). It causes staining of clothes and utensils. It is also not suitable for processing of food, beverages, dyeing, bleaching, etc. The concentration limits of iron in drinking water ranges between 0.3 (maximum acceptable) and $1.0 \mathrm{mg} / \mathrm{L}$ (maximum allowable) (Sharma and Chawla 1977). Iron concentrations of Suri I and II blocks range between $0.0-1.8 \mathrm{mg} / \mathrm{L}$ in post-monsoon and $0.0-6.1 \mathrm{mg} / \mathrm{L}$ in pre-monsoon (figure 9a, b). At Bhagabanbati Primary School, the iron concentration is above the desirable limit $(0.30 \mathrm{mg} / \mathrm{L})$ during both post- and pre-monsoon. High iron concentration affects the taste of water, has adverse effects on domestic uses and promotes growth of iron bacteria. Measures should be taken before consumption by installation of iron removing plants.

Sodium concentration in water varies from 7.00$58.3 \mathrm{mg} / \mathrm{L}$ with an average of $26.04 \mathrm{mg} / \mathrm{L}$ in postmonsoon and $8.0-69.0 \mathrm{mg} / \mathrm{L}$ with an average of $30.5 \mathrm{mg} / \mathrm{L}$ in pre-monsoon periods (figure $8 \mathrm{a}, \mathrm{b}$ ). Sodium regulates blood pressure levels in the human body and increased levels of sodium in blood leads to rise in blood pressure. Potassium controls body balance and maintains normal growth of the human body. Deficiency of potassium might lead to weakness of muscles and rise in blood pressure. No standard limits have been provided by the Bureau of Indian Standards for level of sodium and potassium in drinking water (figure 9). Bicarbonate ion varies from 48.80 to $1073.60 \mathrm{mg} / \mathrm{L}$ and 48.8 to $292.8 \mathrm{mg} / \mathrm{L}$ in post- and pre-monsoon, respectively (figure 10a, b). No standard limits have been provided by the Bureau of Indian Standards for level of carbonate and bicarbonate in drinking water.

Acceptable limit of chloride in drinking water is $250 \mathrm{mg} / \mathrm{L}(1000 \mathrm{mg} / \mathrm{L}$ in case of no other alternative source) (BIS 2012). Chloride concentration in groundwater samples in the study area ranged from 15.0 to $124.96 \mathrm{mg} / \mathrm{L}$ and 15.0 to $274.9 \mathrm{mg} / \mathrm{L}$ in post- and pre-monsoon, respectively (figure 11a, b). Too much of chloride leads to bad taste in water and also chloride ion combines with $\mathrm{Na}$ (that is being derived from the weathering of granitic terrains) and forms $\mathrm{NaCl}$, whose excess presence in water makes it saline and unfit for both irrigational and drinking purposes. Increase in chloride levels in our body might lead to increase in blood pressure levels and rise in body fluids. As exhibited by contours, chloride in water is higher in pre-monsoon in comparison with postmonsoon.

The sulfate ion causes no particular harmful effects on soils or plants; however, it contributes in increasing the salinity in the soil solution. Sulfate ion varied from 0.43 to $48.76 \mathrm{mg} / \mathrm{L}$ during post-monsoon and 0.1 to $56.7 \mathrm{mg} / \mathrm{L}$ in premonsoon periods (figure 12a, b). Acceptable limit of sulfate in drinking water is $200 \mathrm{mg} / \mathrm{L}(400$ $\mathrm{mg} / \mathrm{L}$ in case of no other alternative source) (BIS 2012). Excess sulfate consumption through water might lead to occurrence of diarrhoea in humans. 


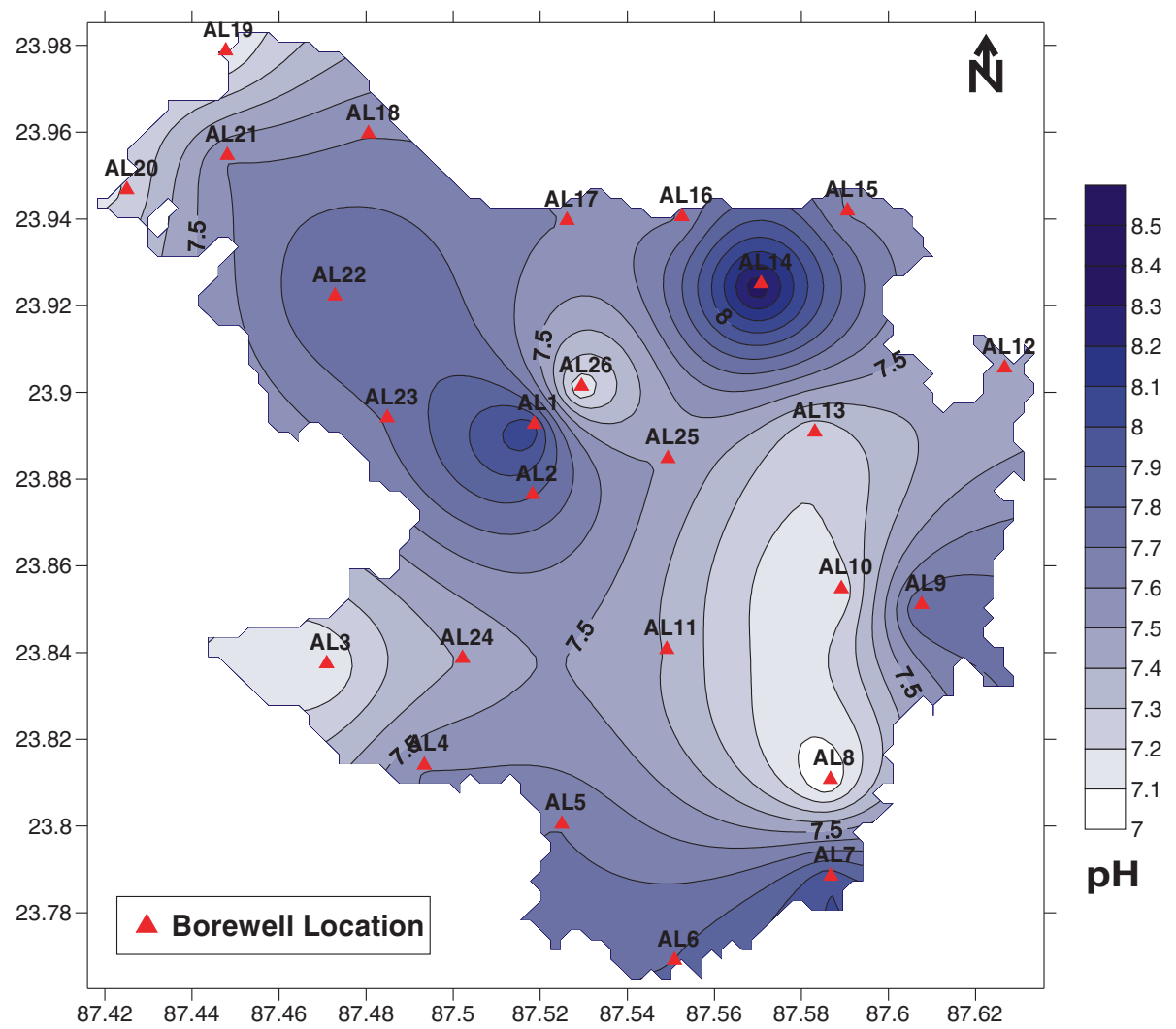

(a)

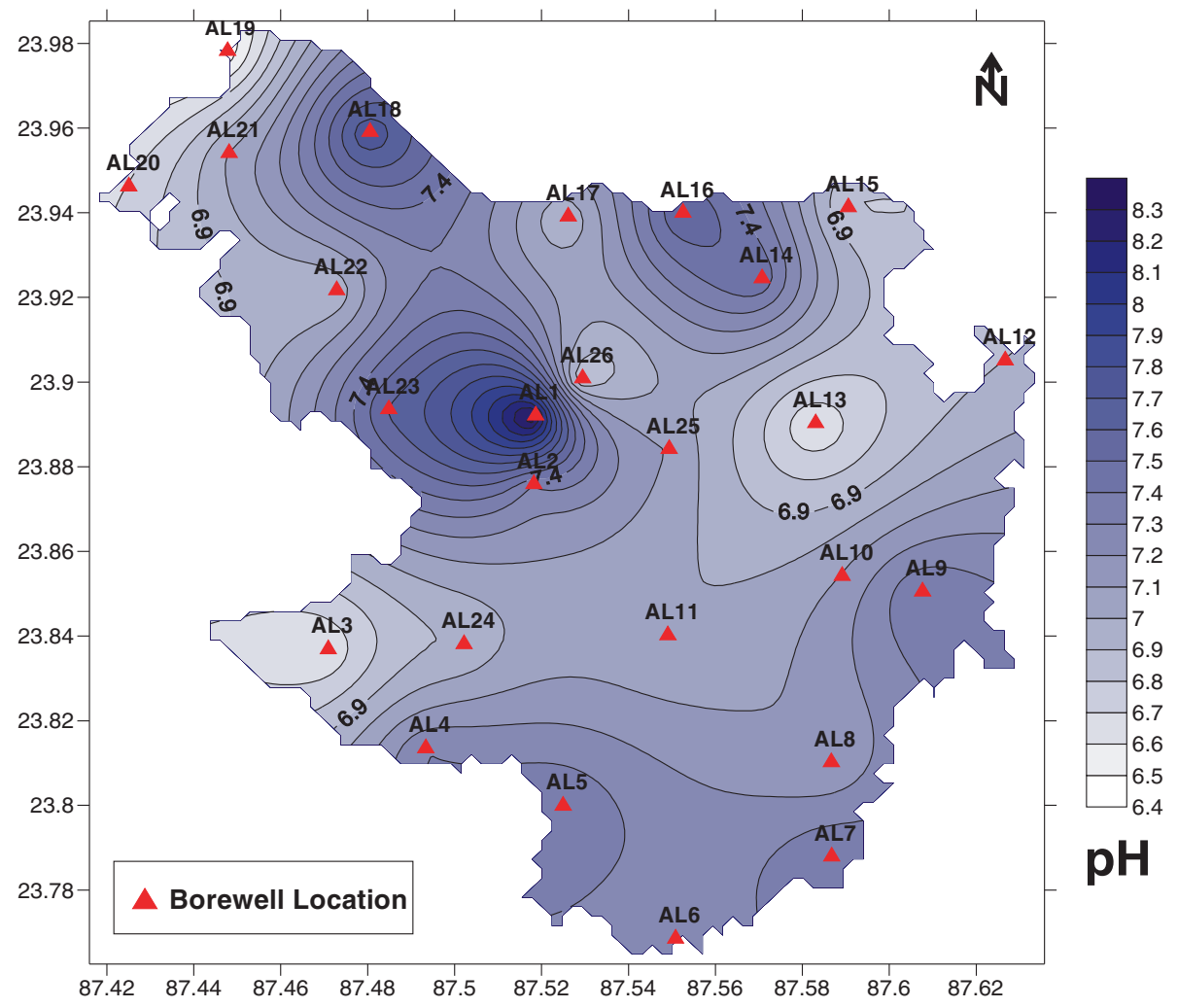

(b)

Figure 2. Spatial distribution of $\mathrm{pH}$ (a) post-monsoon and (b) pre-monsoon. 


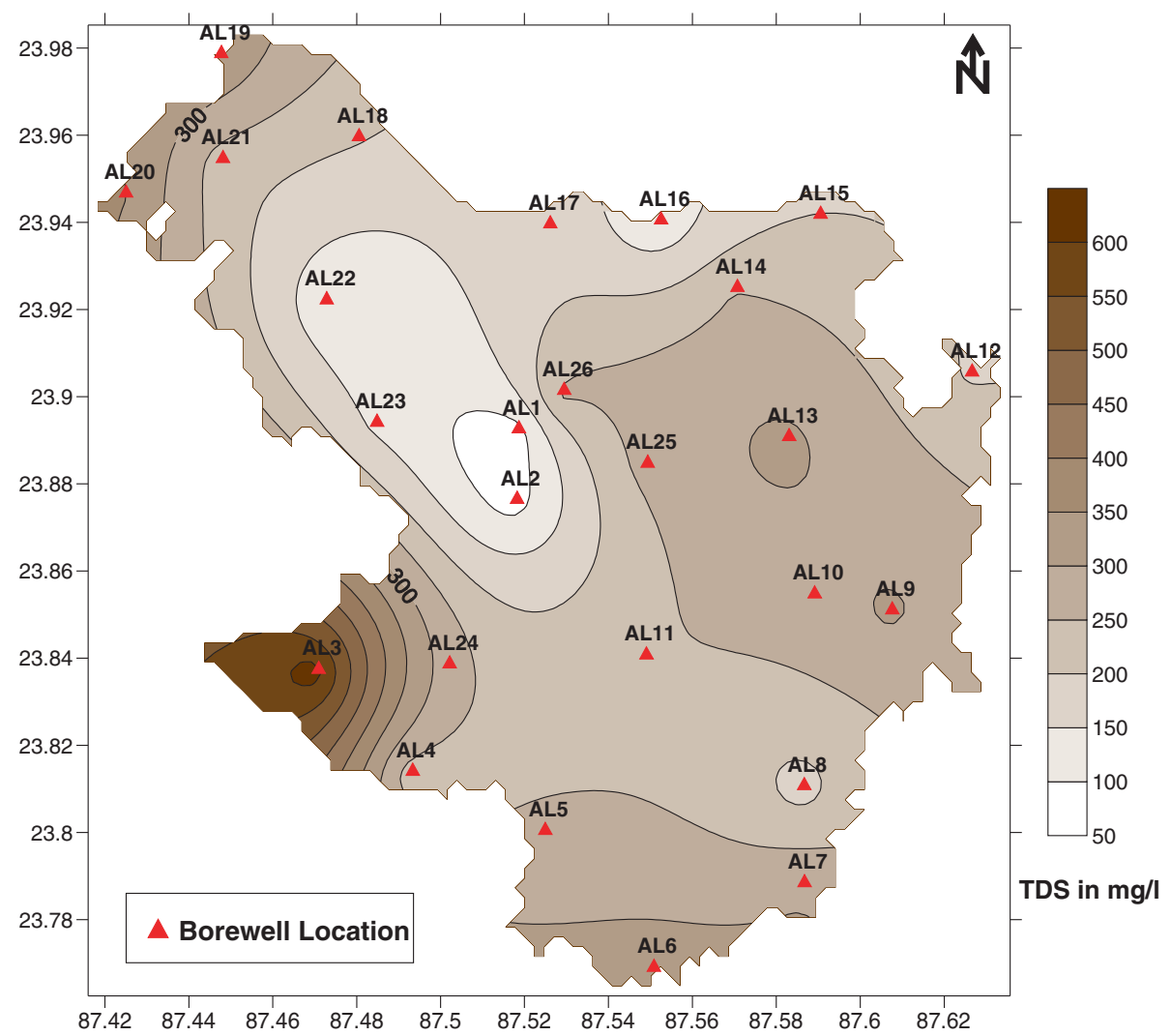

(a)

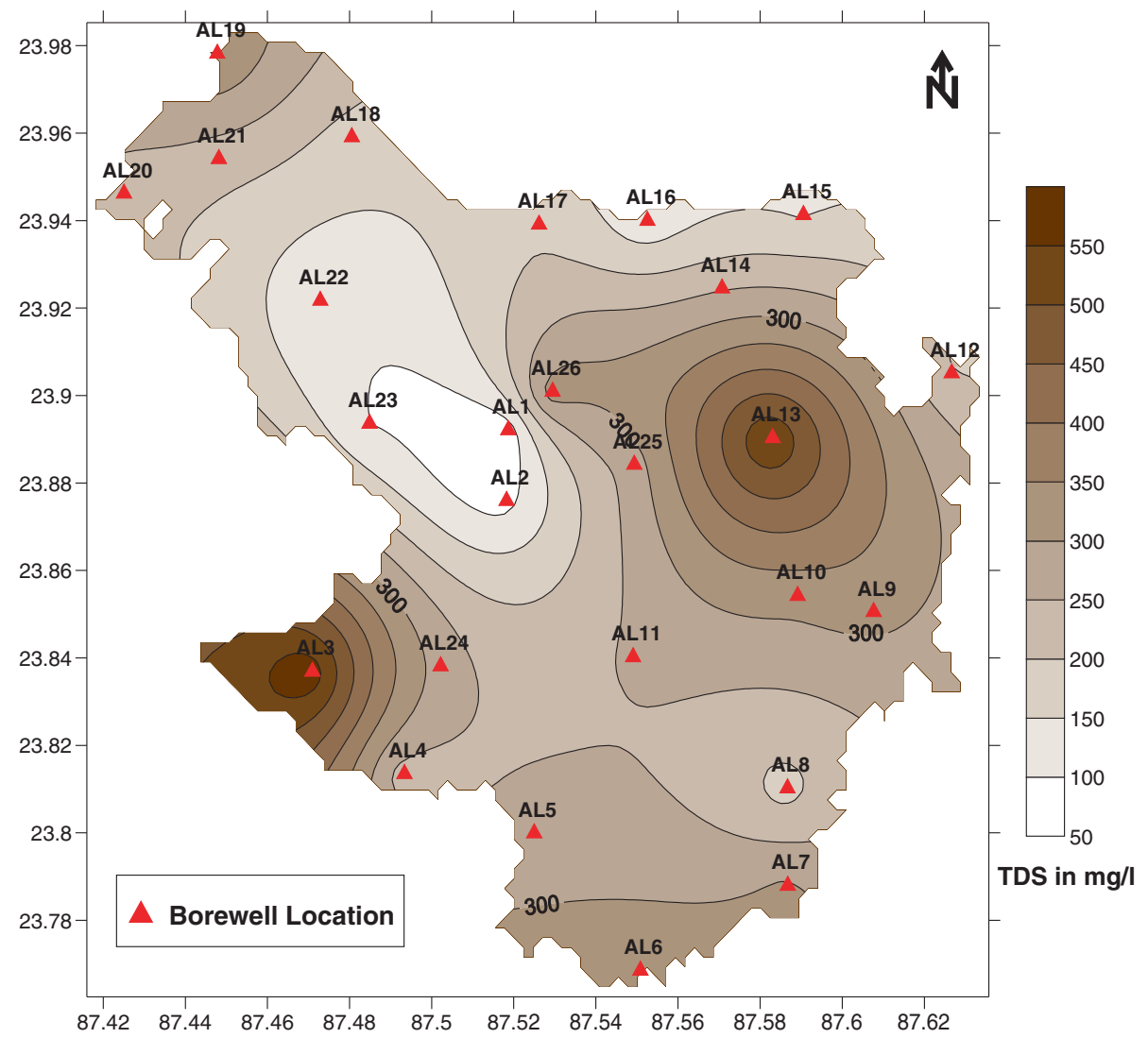

(b)

Figure 3. Spatial distribution of TDS (a) post-monsoon and (b) pre-monsoon. 


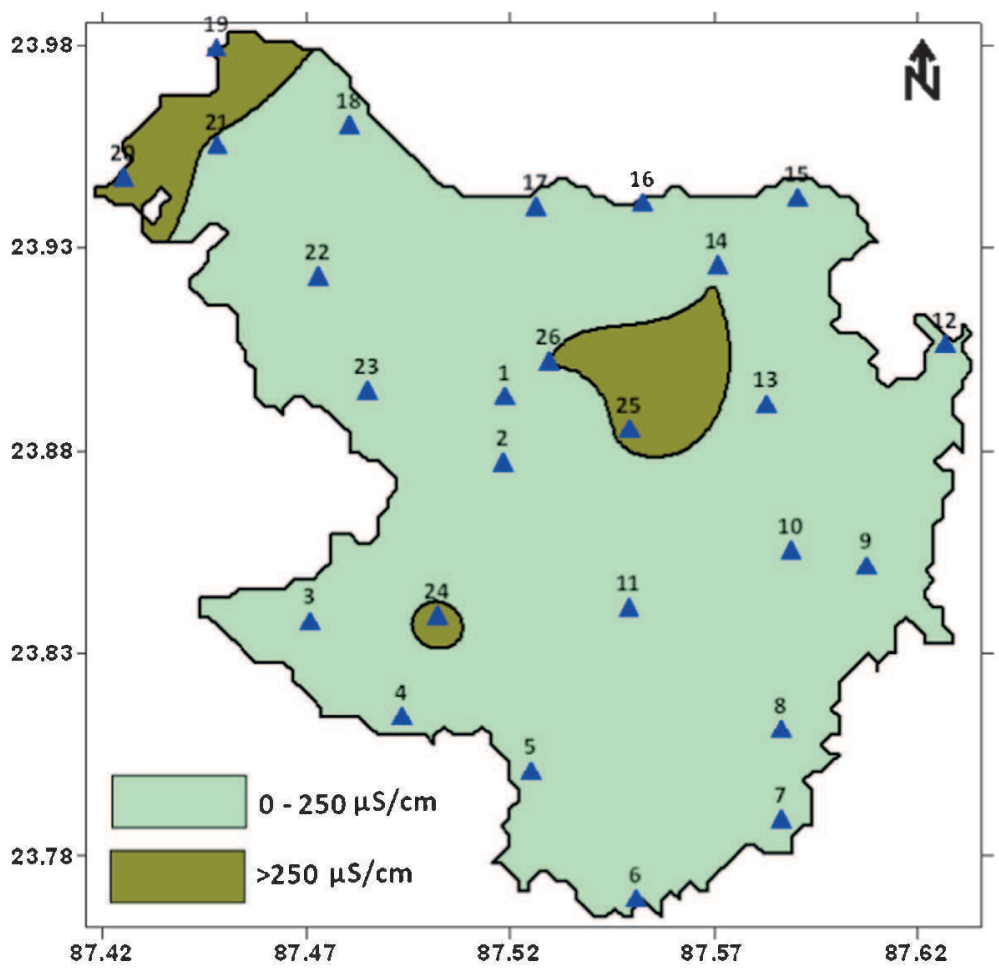

(a)

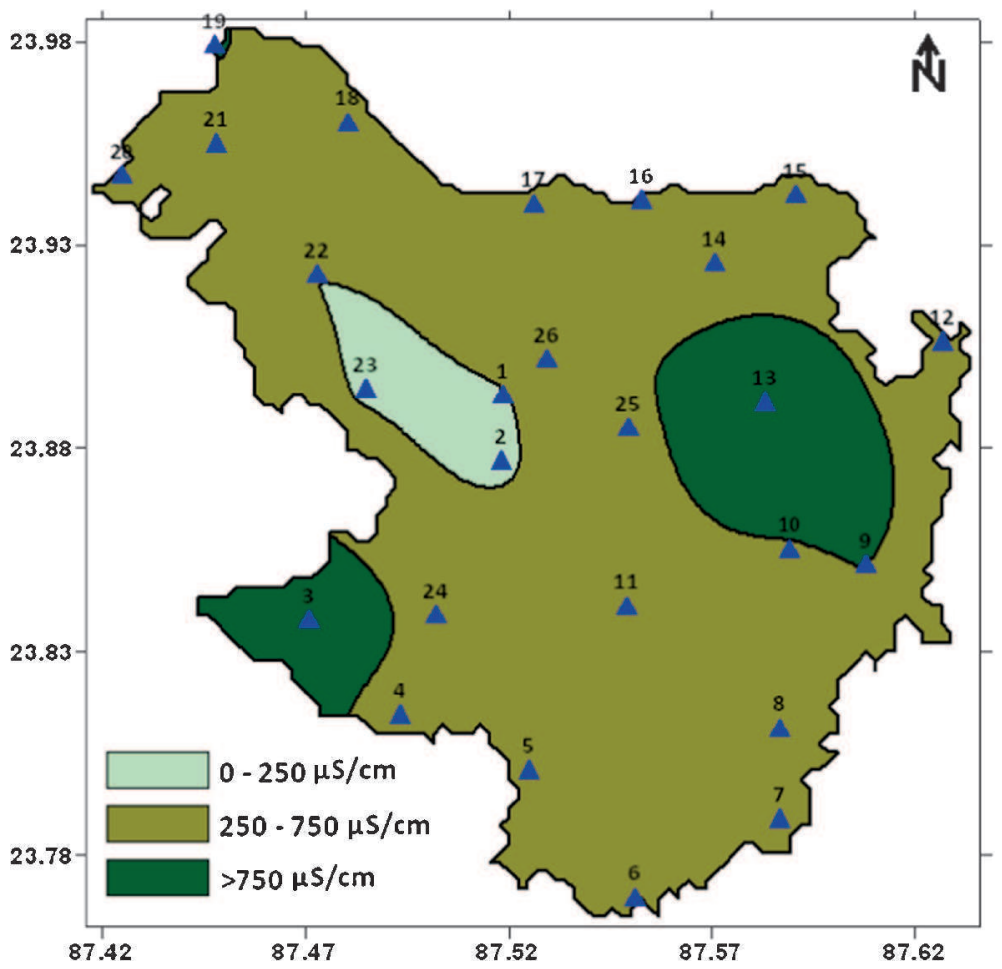

(b)

Figure 4. Spatial distribution of EC (a) post-monsoon and (b) pre-monsoon.

The physico-chemical parameters determined along with range of analysed parameters as well as their mean and standard deviation values are presented in table 1.

\subsection{Ionic balance}

Ionic balance of a water sample is calculated to identify the dominant ionic type, i.e., cationic or 


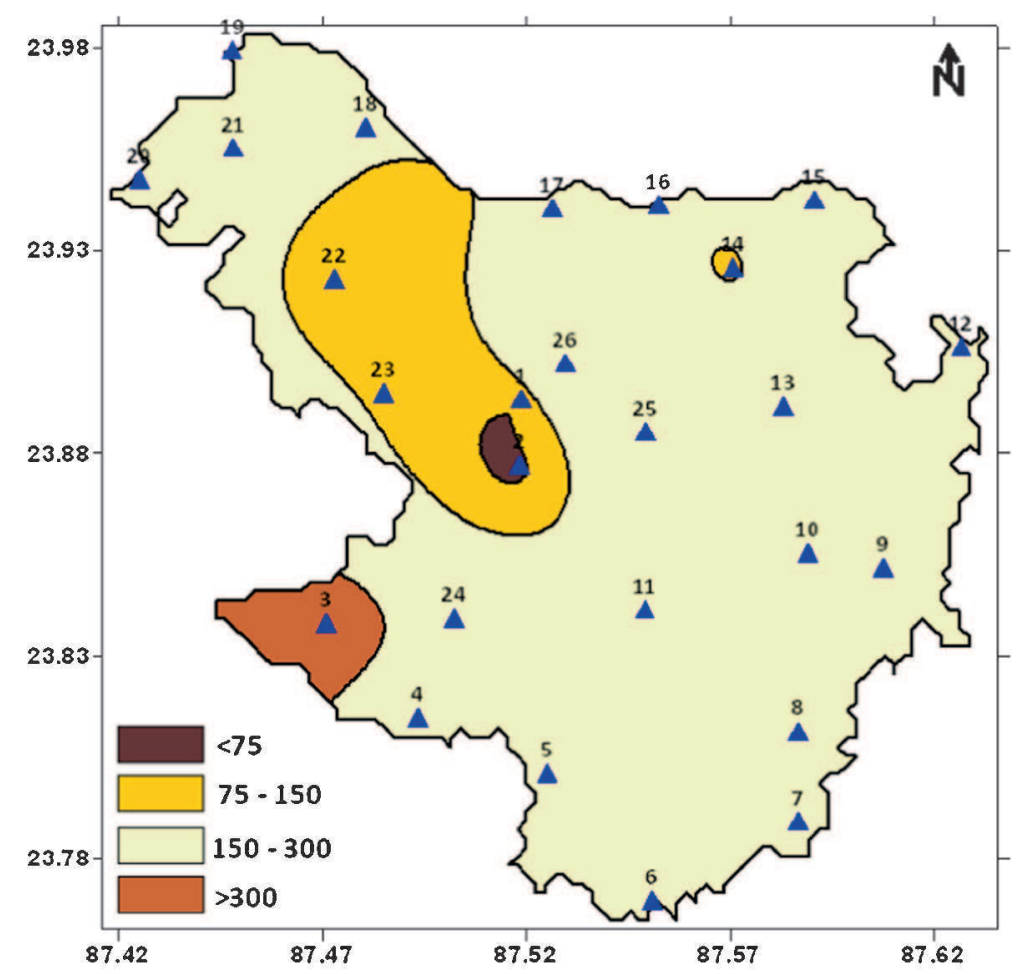

(a)

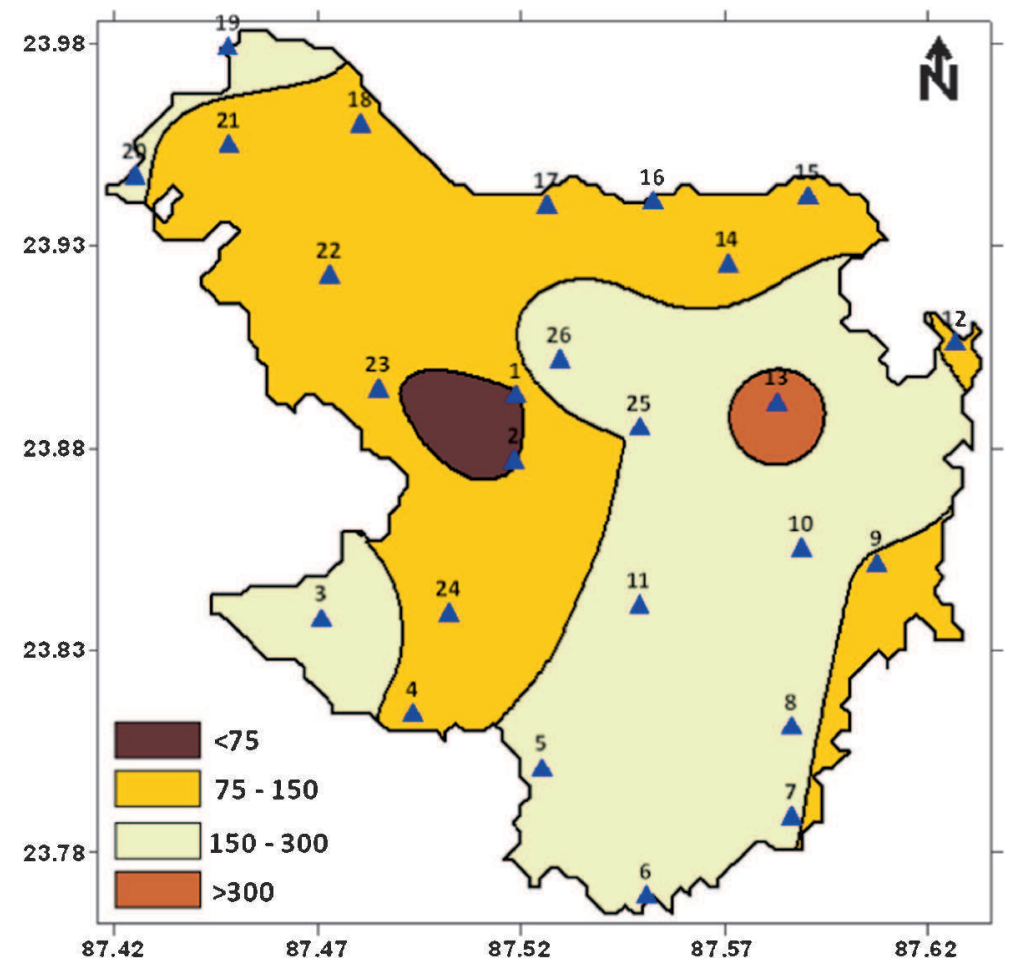

(b)

Figure 5. Spatial distribution of TH (a) post-monsoon and (b) pre-monsoon.

anionic in the water sample. For calculation of ion balance in water, concentration of each cation and anion in groundwater sample is calculated in meq/L. The standard formula for calculating ion balance in water is as follows (Huh et al. 1998):

$$
\begin{aligned}
\text { Ion balance }= & {\left[100 *\left(\sum \text { cation }-\sum \text { anion }\right)\right] } \\
& /\left[\sum \text { cation }+\sum \text { anion }\right] .
\end{aligned}
$$




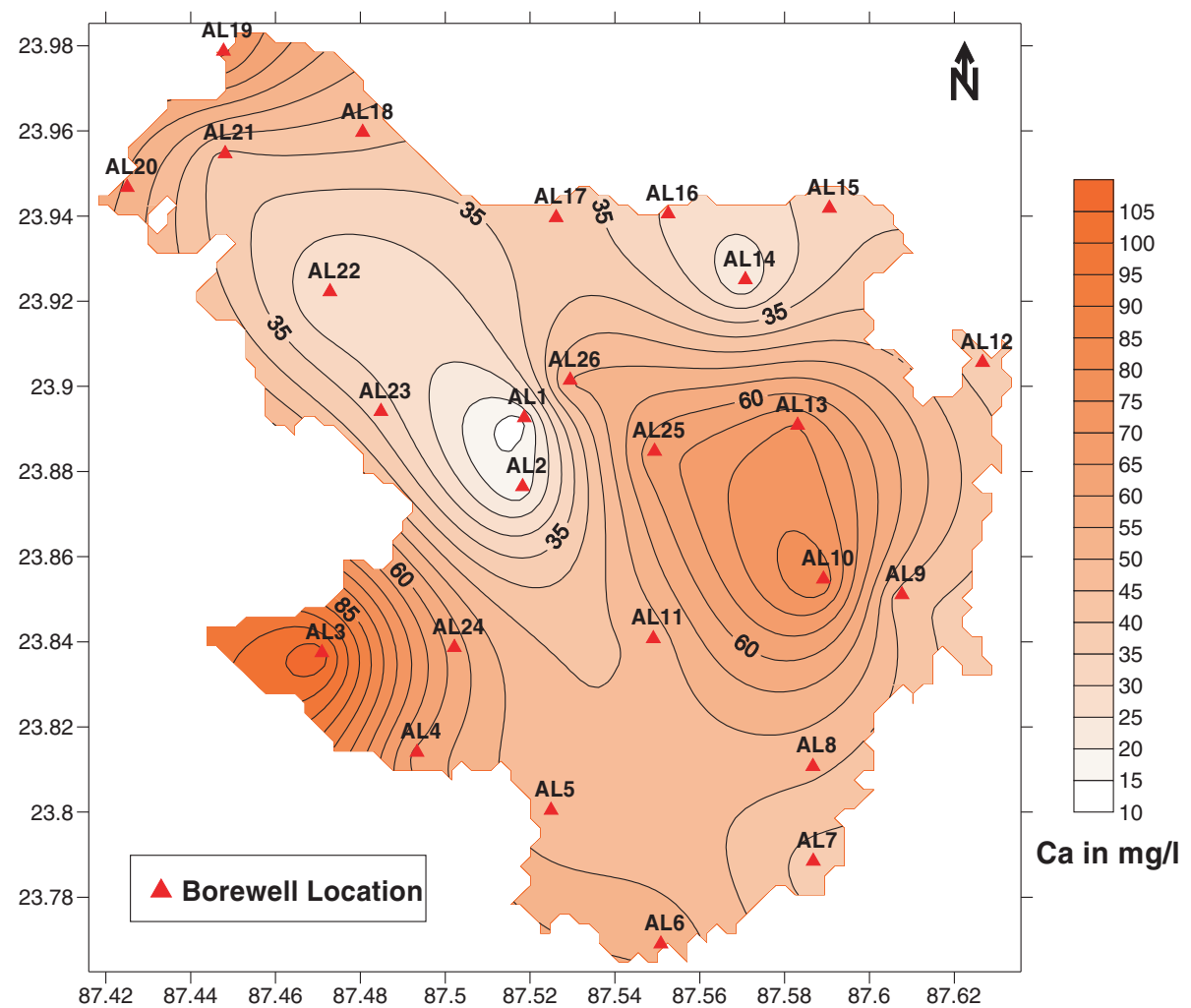

(a)

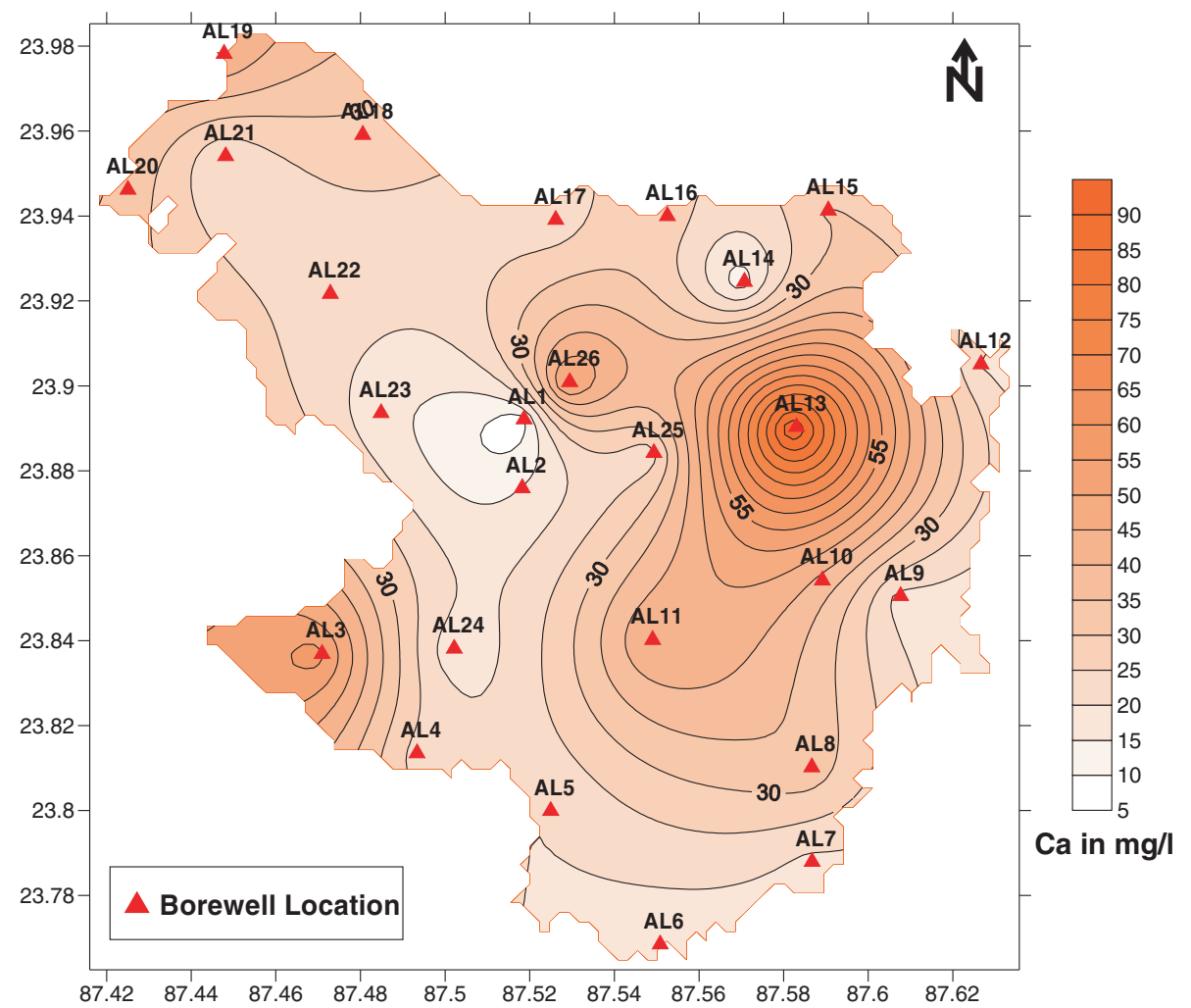

(b)

Figure 6. Spatial distribution of $\mathrm{Ca}^{2+}$ (a) post-monsoon and (b) pre-monsoon.

Ion balance of groundwater represents the fractional difference between the total cations and total anions and also indicates quality of water keeping in mind the total dissolved solids of a water sample. According to standard rules, the ion balance of a fresh water sample with low TDS is considered 


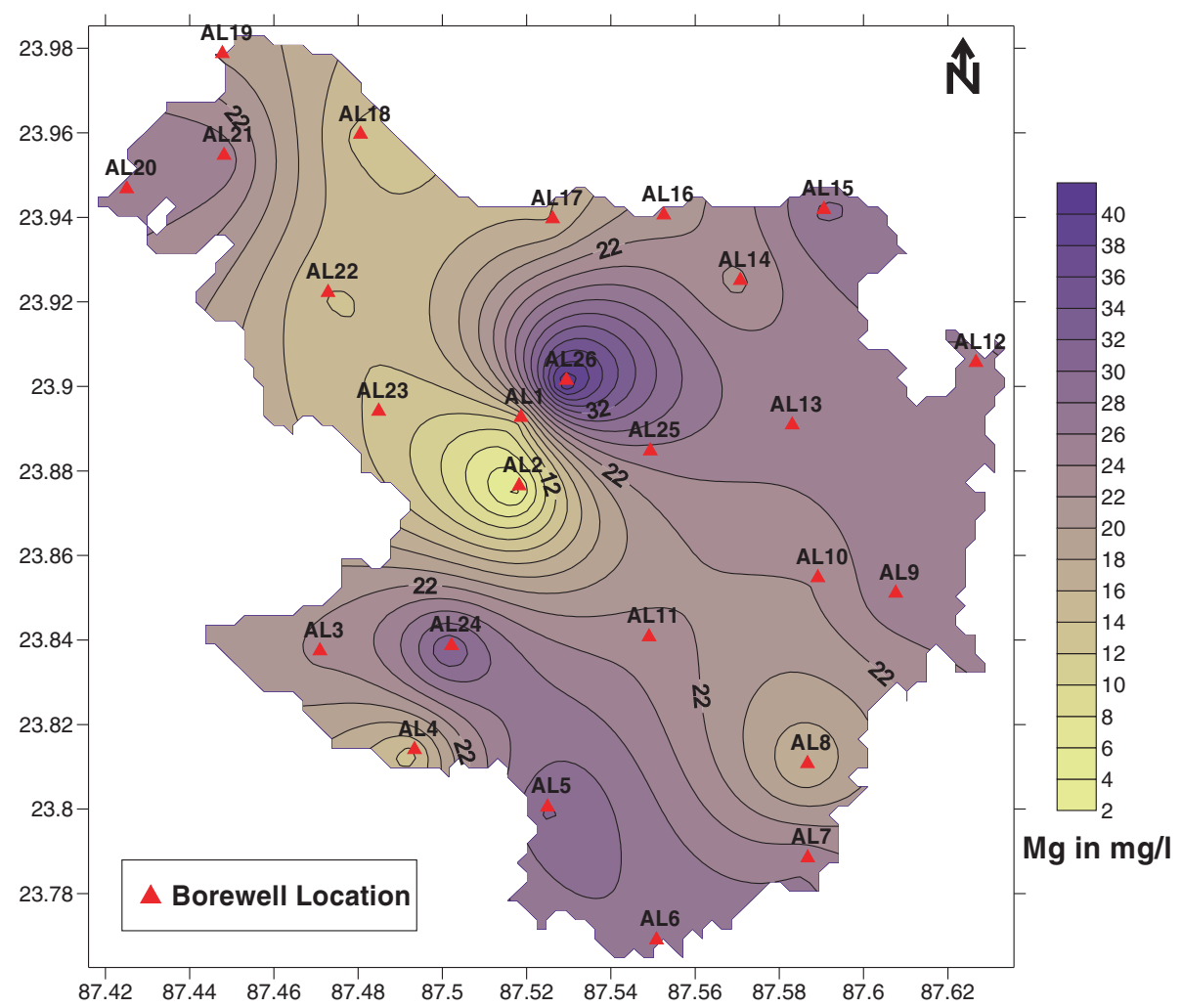

(a)

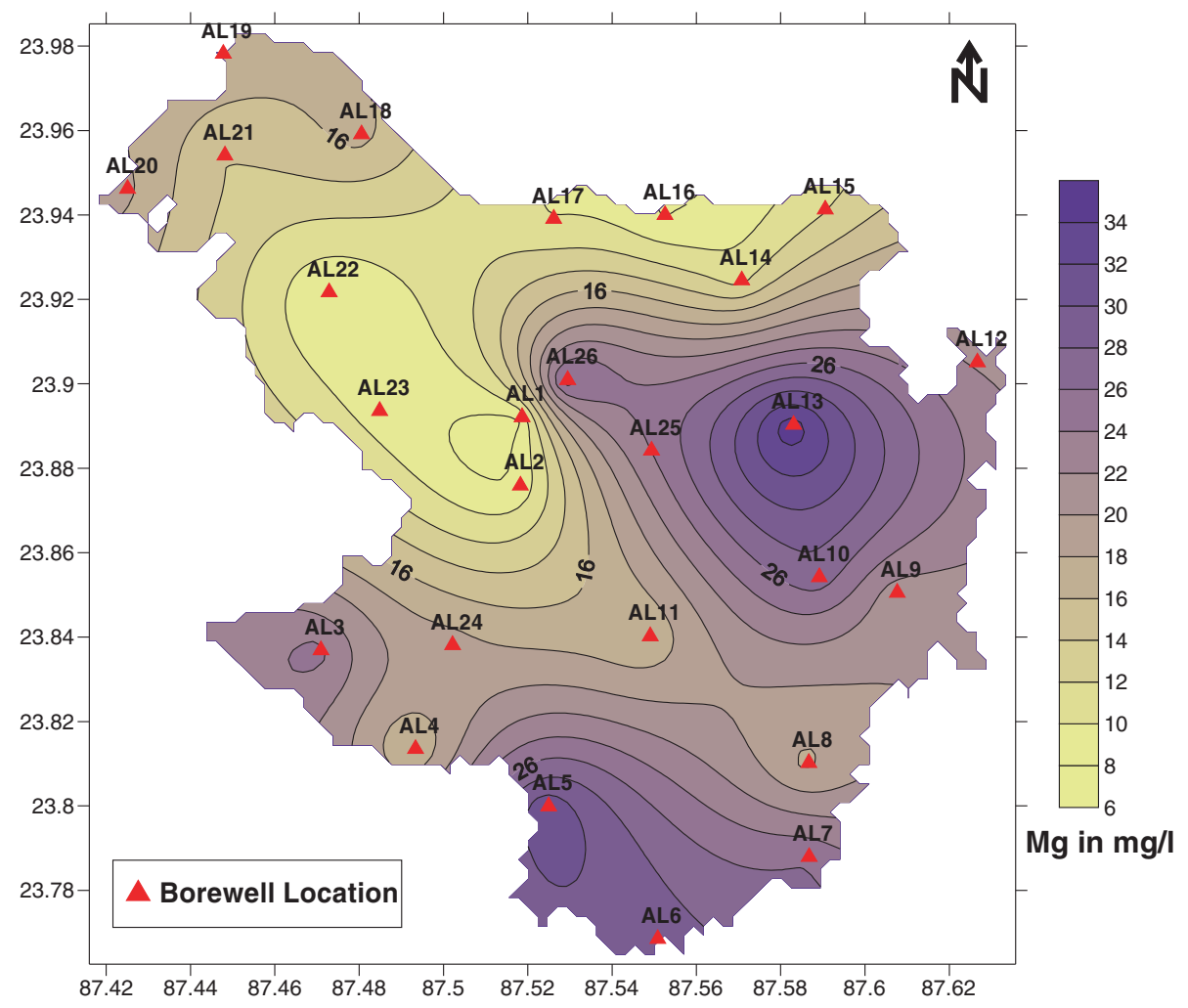

(b)

Figure 7. Spatial distribution of $\mathrm{Mg}^{2+}$ (a) post-monsoon and (b) pre-monsoon. 


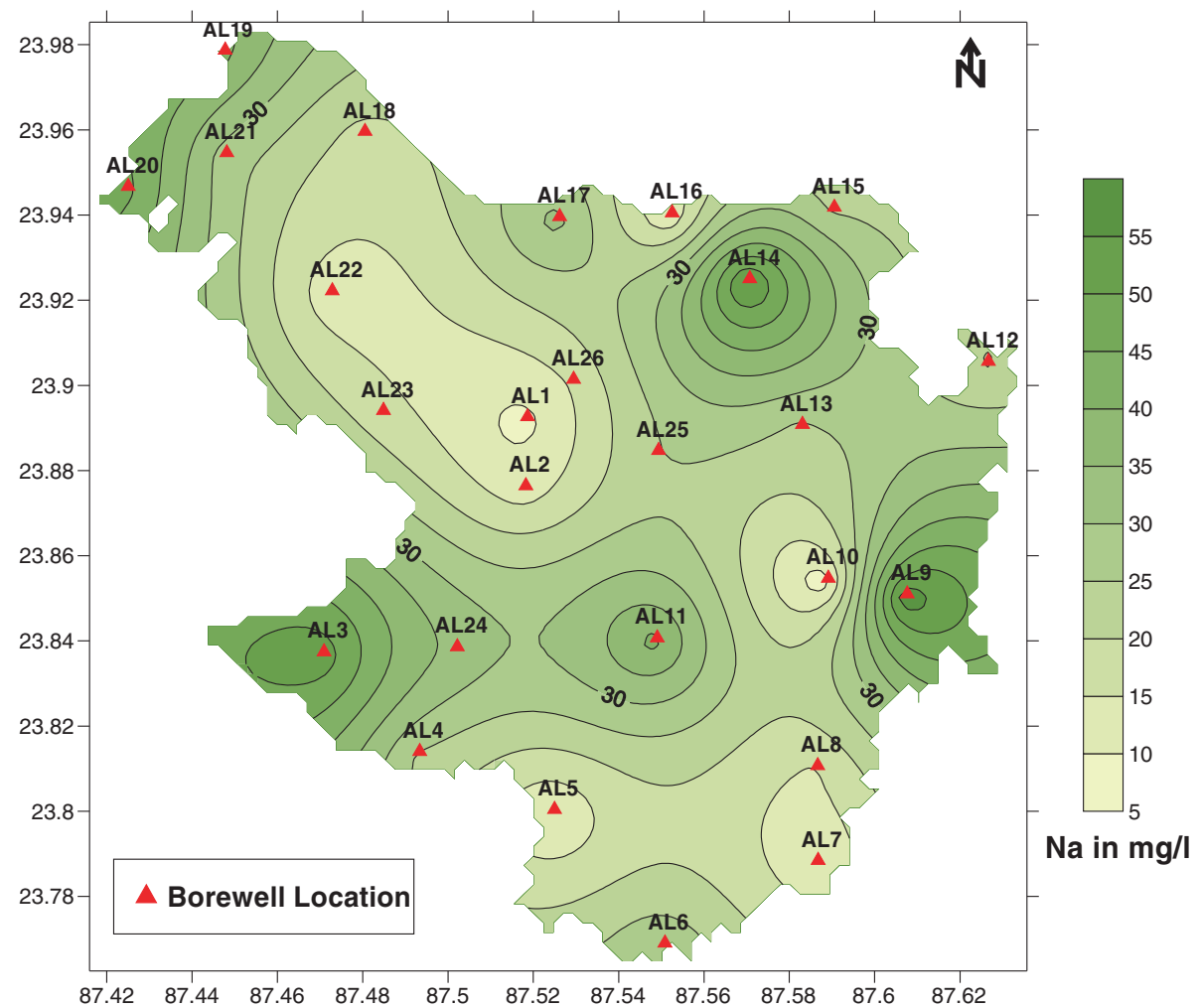

(a)

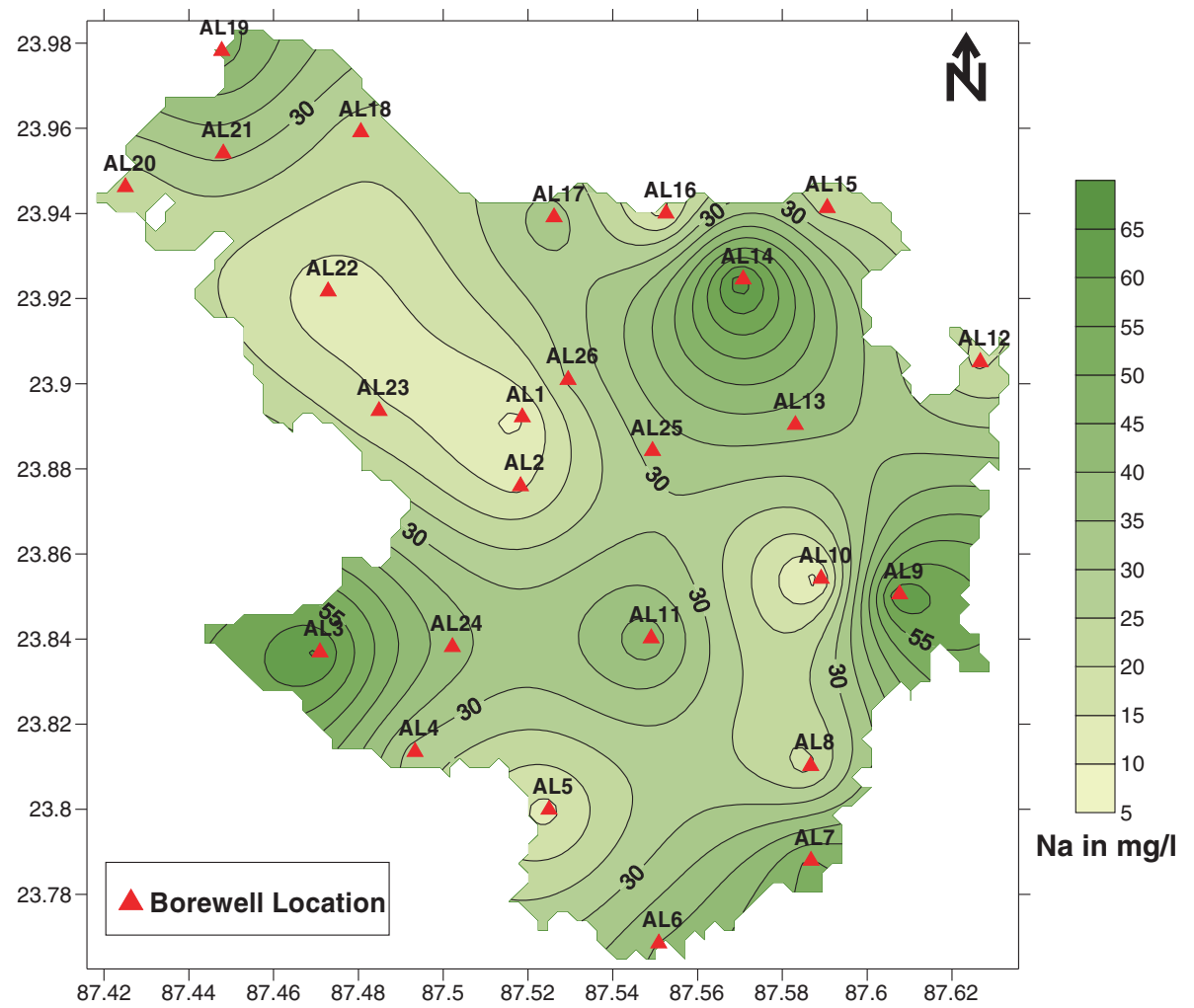

(b)

Figure 8. Spatial distribution of $\mathrm{Na}^{+}$(a) post-monsoon and (b) pre-monsoon. 


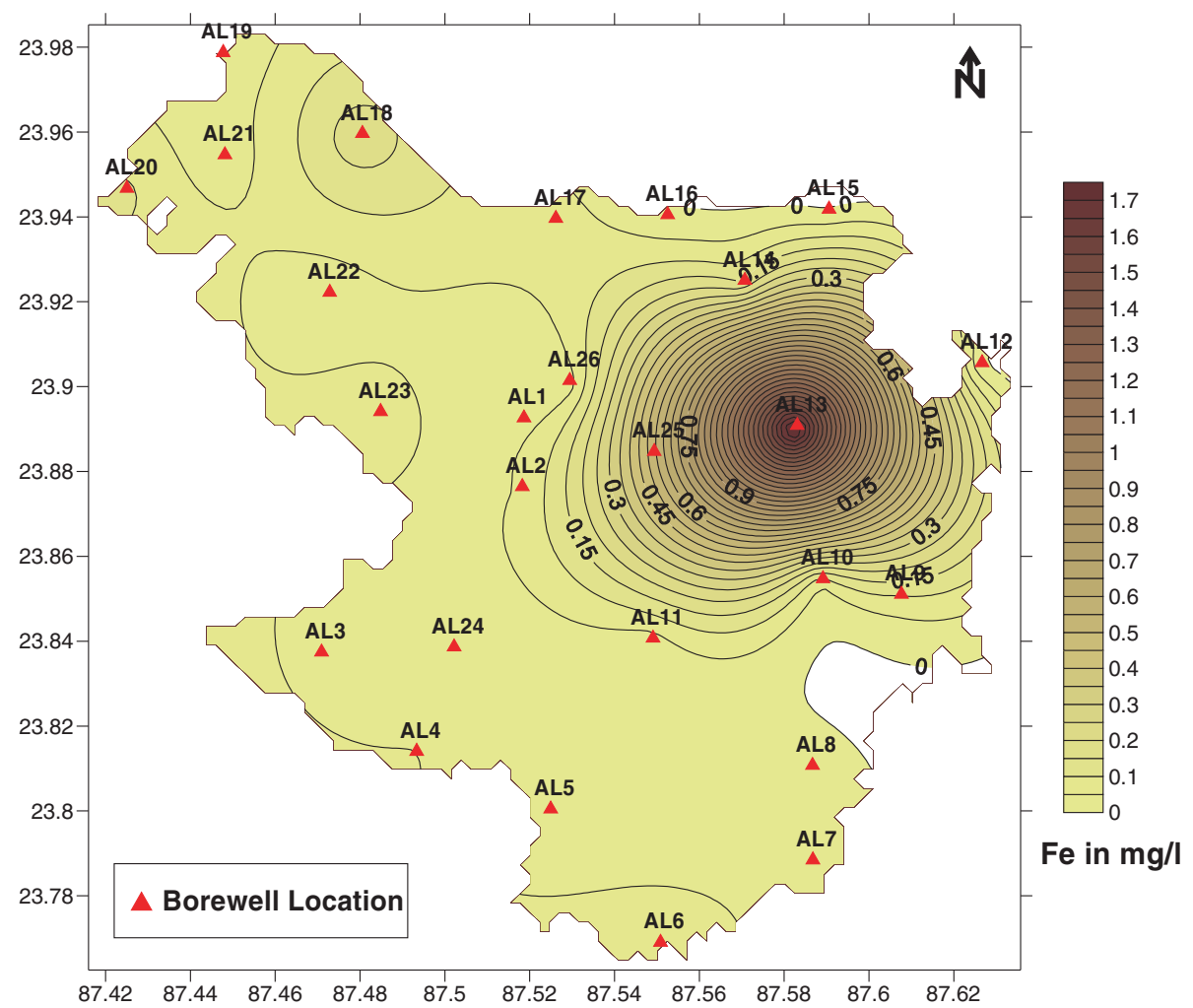

(a)

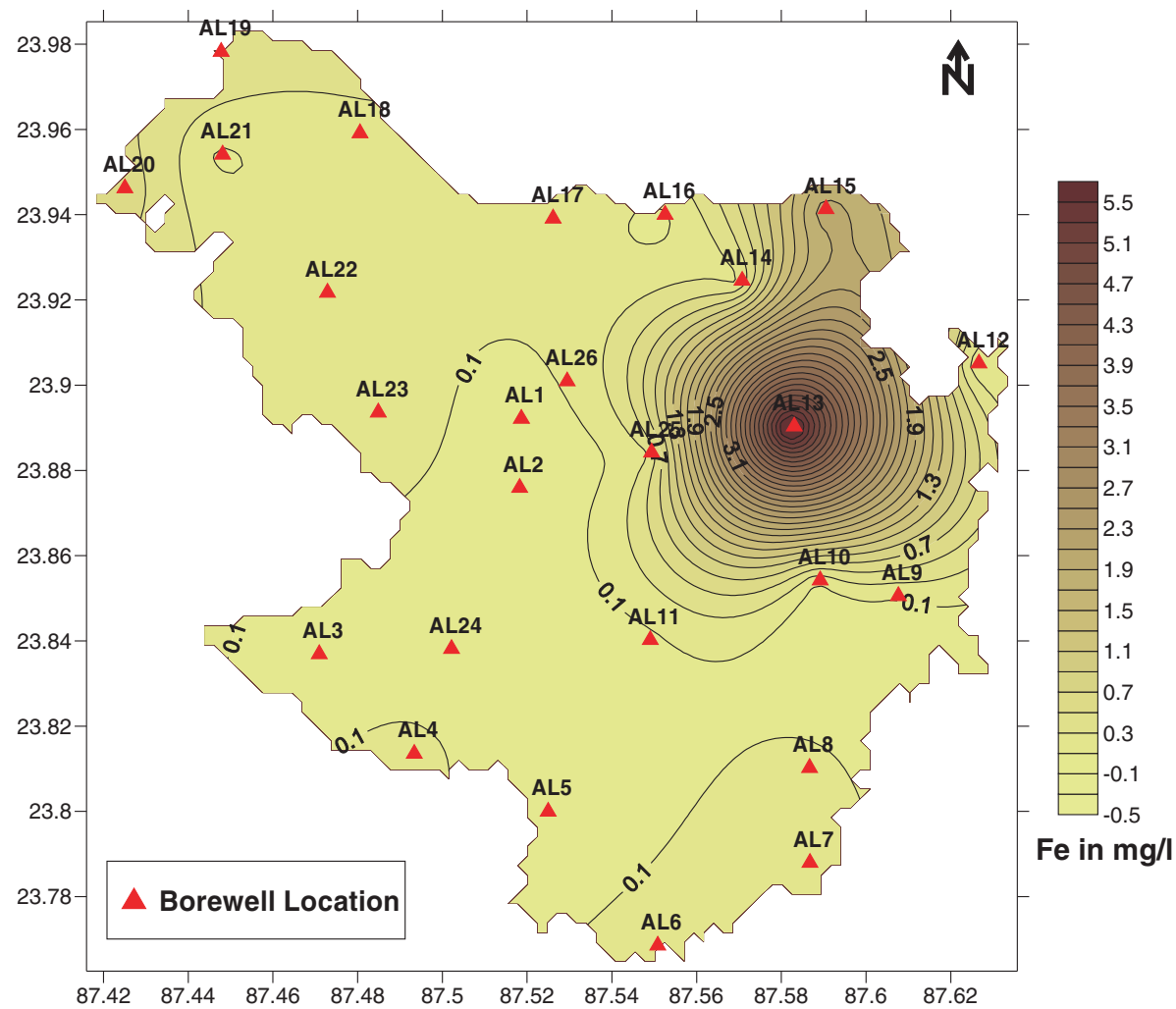

(b)

Figure 9. Spatial distribution of $\mathrm{Fe}^{2+}$ (a) post-monsoon and (b) pre-monsoon. 


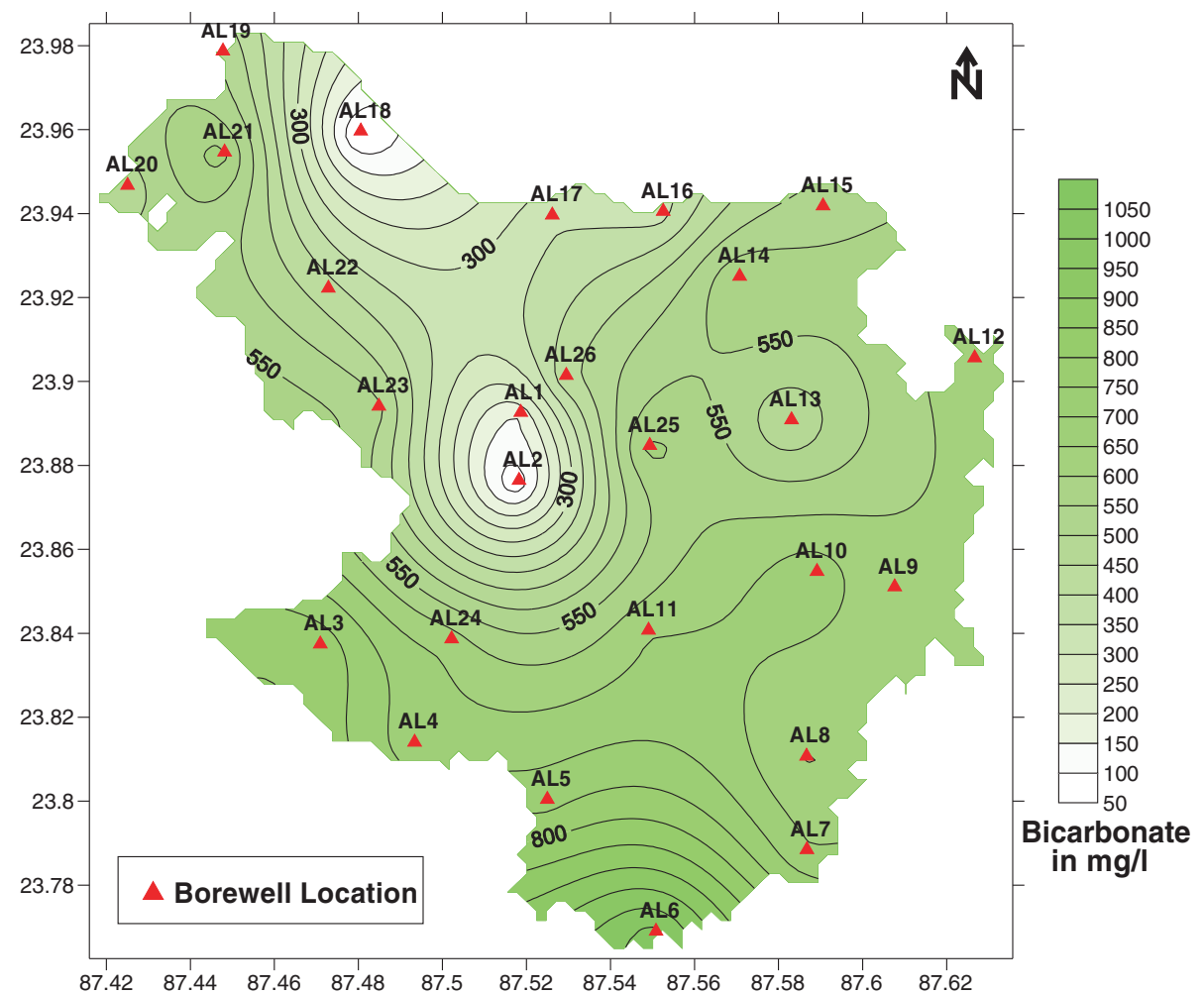

(a)

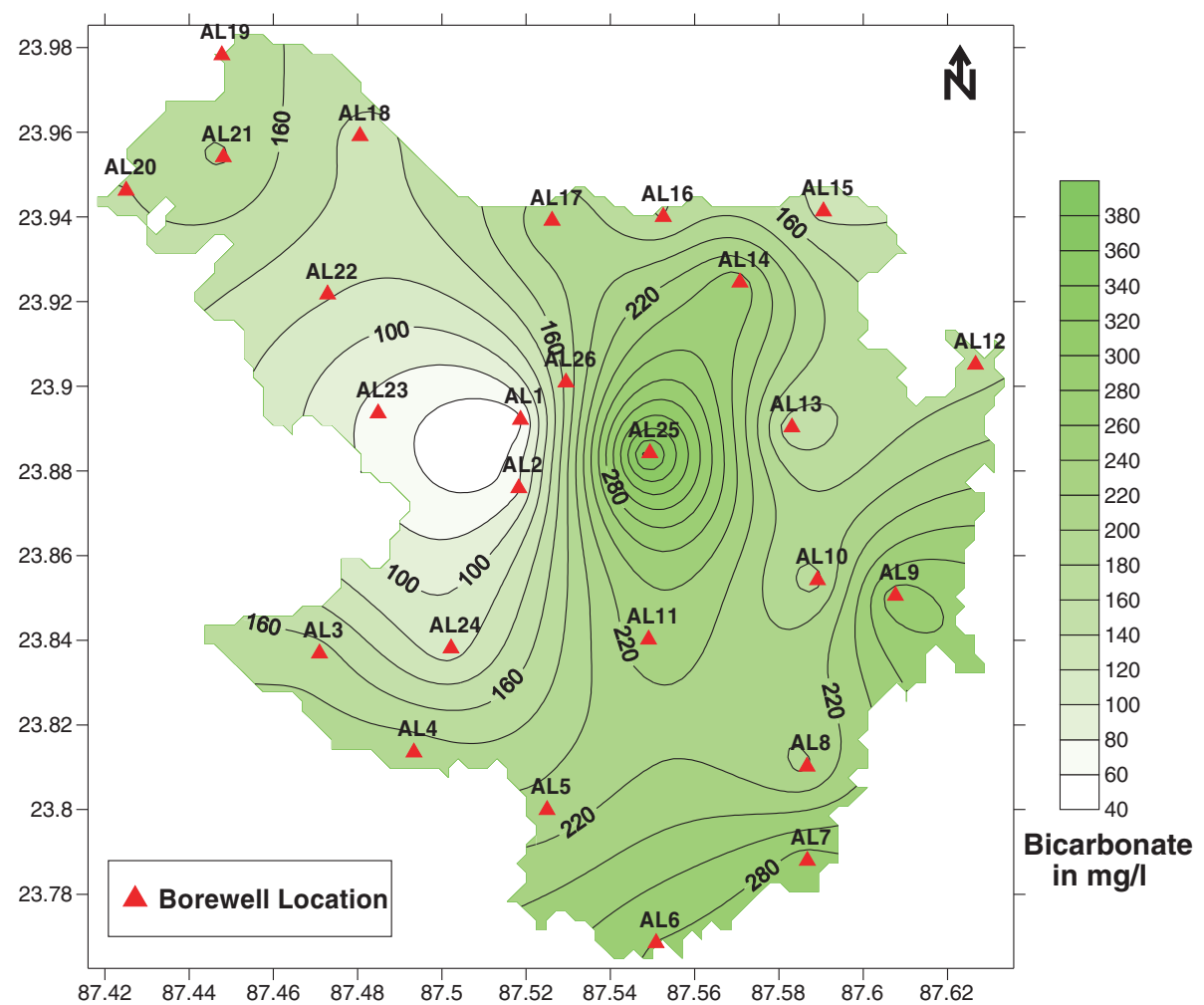

(b)

Figure 10. Spatial distribution of $\mathrm{HCO}_{3}^{-}$(a) post-monsoon and (b) pre-monsoon.

to be good if the value is between $-10 \%$ and $+10 \%$. In the post-monsoon session, ion balance of all water samples barring one, from Singur area, are all negative and less than $-10 \%$, the lowest values being even lesser than $-50 \%$. In pre-monsoon, the results are completely opposite. Majority of the water samples $(88.5 \%)$ have ion balance values between $-10 \%$ and $+10 \%$. Only three groundwater 


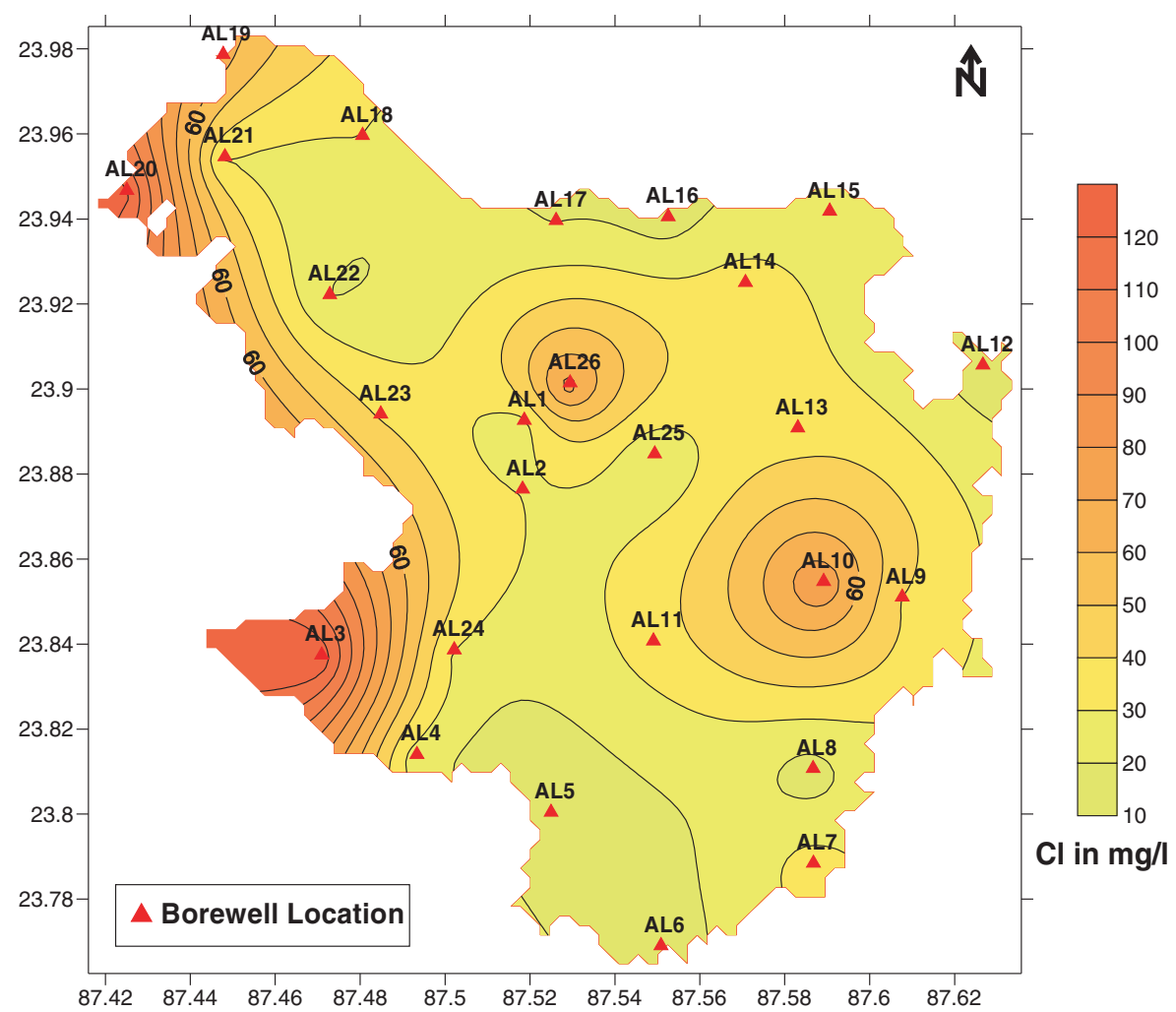

(a)

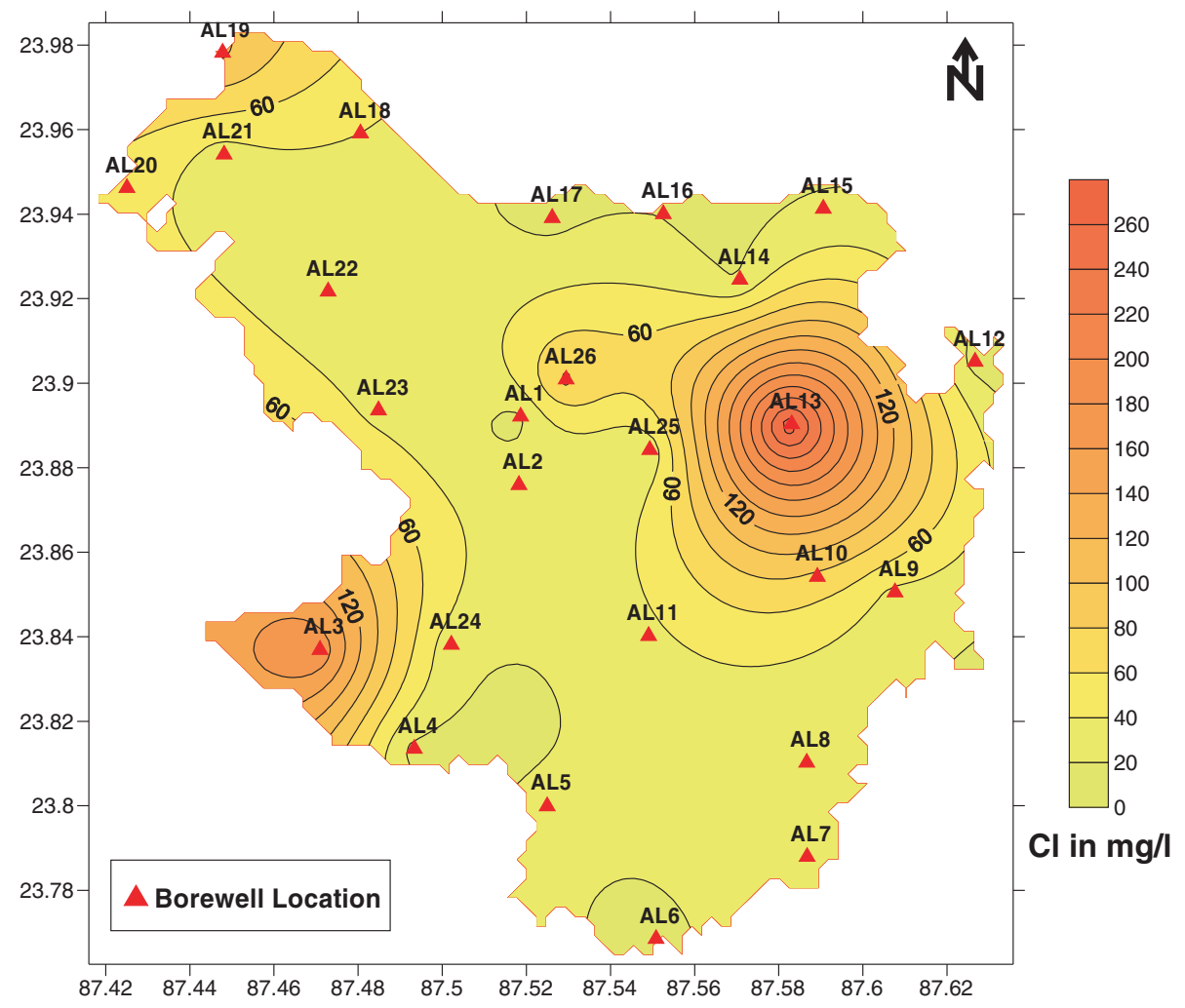

(b)

Figure 11. Spatial distribution of $\mathrm{Cl}^{-}$(a) post-monsoon and (b) pre-monsoon. 


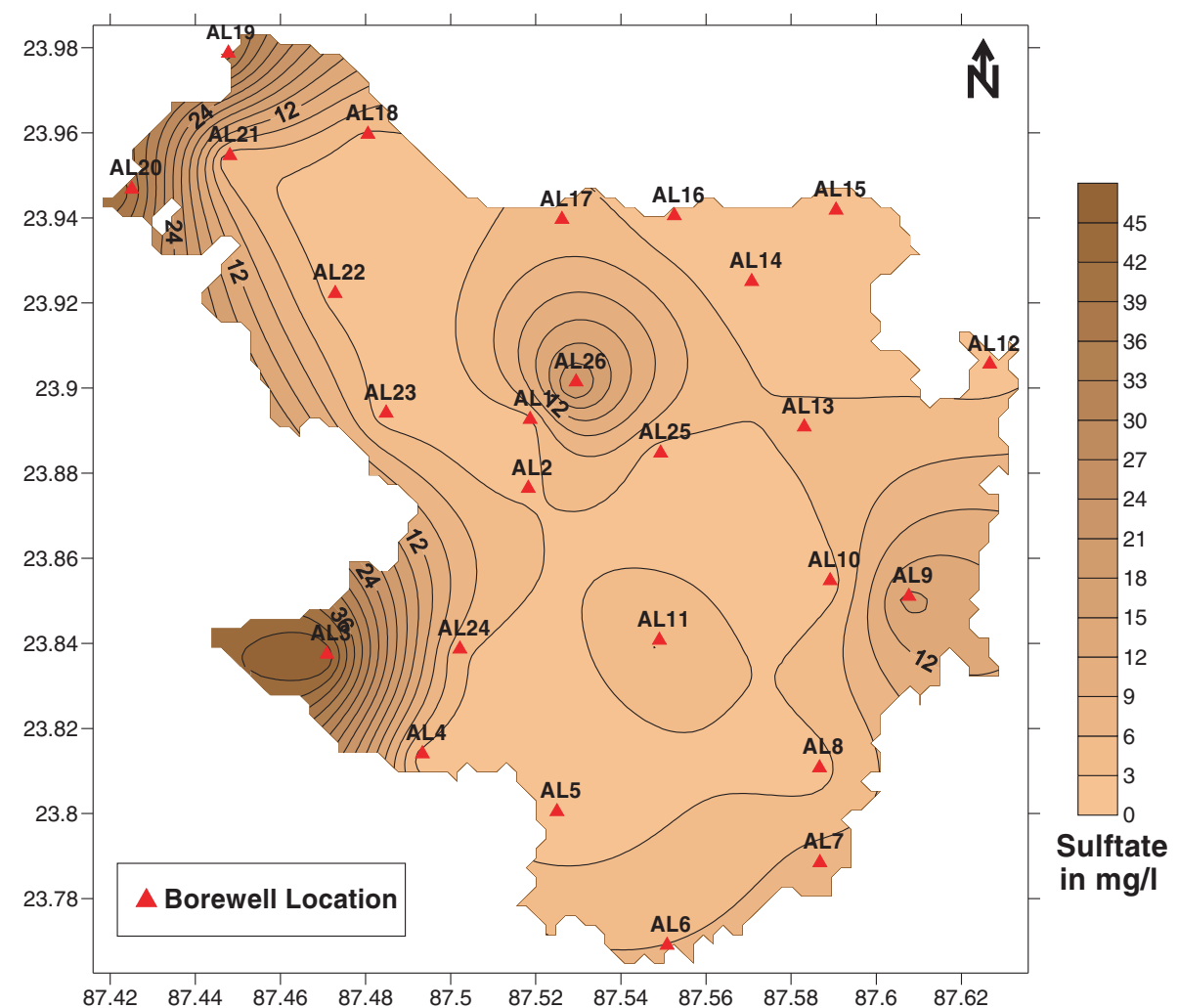

(a)

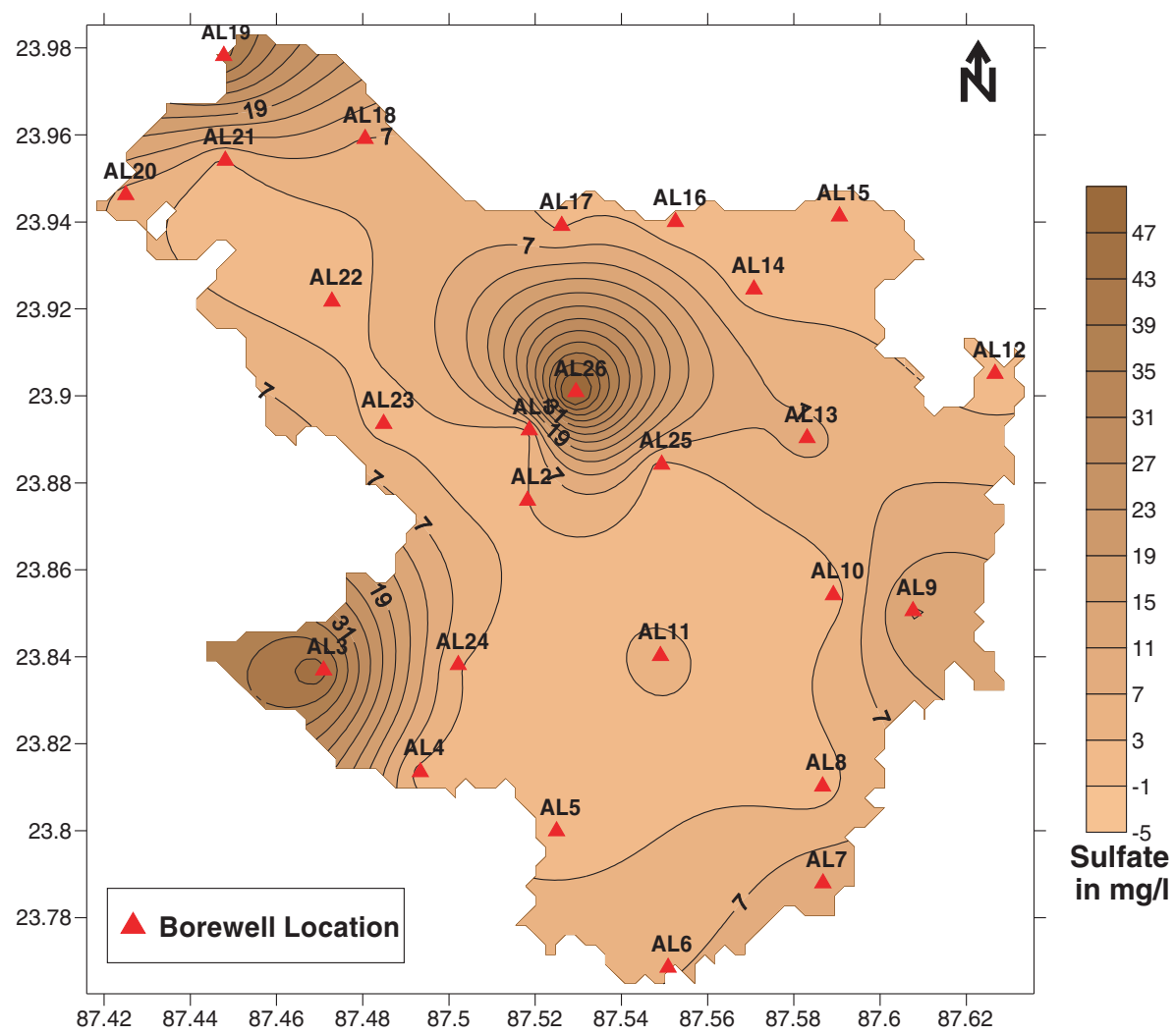

(b)

Figure 12. Spatial distribution of $\mathrm{SO}_{4}^{2-}$ (a) post-monsoon and (b) pre-monsoon. 
samples (Bhagabanbati, Gobindopur and Agar) have ion balance values falling outside the desirable range.

\subsection{Water quality for irrigation purposes}

To assess the overall irrigational water quality of the samples collected, six computed water quality parameters have been considered; namely Sodium Adsorption Ratio (SAR), Soluble Sodium Percentage (SSP), Permeability Index (PI), Residual Sodium Carbonate (RSC), Magnesium Adsorption Ratio and Kelly's Ratio (Ishaku et al. 2011; Obiefuna and Sheriff 2011). Table 2 represents evaluated values of these parameters for all 26 sampling locations. Table 3 shows classification of samples according to standards specified for different water quality parameters.

\subsection{Sodium adsorption ratio ( $S A R$ )}

Sodium adsorption ratio is a measure of the sodicity of the soil determined through quantitative chemical analysis of water in contact with it. An excess of $\mathrm{HCO}_{3}^{-}$and $\mathrm{CO}_{3}^{2-}$ ions in water react with $\mathrm{Na}^{+}$in soil, resulting in a sodium hazard (Wadie and Abduljalil 2010). SAR values are plotted against EC values (in $\mu \mathrm{S} / \mathrm{cm}$ ) on the US salinity diagram to categorize analyzed water samples according to their irrigational suitability quotient. The sodium adsorption ratio (SAR) was calculated using the following equation given by Richards (1954):

$$
\mathrm{SAR}=\left[\mathrm{Na}^{+}\right] /\left\{\left(\left[\mathrm{Ca}^{2+}\right]+\left[\mathrm{Mg}^{2+}\right]\right) / 2\right\}^{1 / 2}
$$

where concentrations of all ions have been expressed in meq/L.

In the present study, the SAR values range from 0.18 to 2.07 in post-monsoon and $0.24-3.24$ during pre-monsoon. Based on the SAR values all samples have low sodium hazard and on plotting over the US salinity diagram Lab () (figure 13), the water samples fall in the C1-S1 and C2-S1 classes (postmonsoon) and C1-S1, C2-S1 and C3-S1 classes (premonsoon), and hence can be considered moderately suitable for irrigation.

\subsection{Soluble sodium percentage (SSP)}

Soluble sodium percentage (SSP) is used to evaluate sodium hazard. High sodium ion concentration in soil can take a toll on internal drainage patterns in soil as release of calcium and magnesium ions are facilitated due to absorption of sodium by clay particles. Water with an SSP greater than $60 \%$ may result in sodium accumulations that will cause a breakdown in the soil's physical properties (Khodapanah et al. 2009). Soluble sodium percentage (SSP) (Raghunath 1987) was calculated using the following equation:

$$
\mathrm{SSP}=\frac{\left[\left(\mathrm{Na}^{+}+\mathrm{K}^{+}\right) * 100\right]}{\left[\mathrm{Ca}^{2+}+\mathrm{Mg}^{2+}+\mathrm{Na}^{+}+\mathrm{K}^{+}\right]}
$$

where concentrations of all ions have been expressed in meq/L.

The SSP values range from 5.62 to 47.31 in postmonsoon and 7.84-66.3 during pre-monsoon. The SSP values and the EC values have been plotted on the Wilcox diagram (Wilcox 1955) (figure 14) and are found to fall under the 'Very Good to Good' and 'Good to Permissible' categories during postand pre-monsoon, respectively.

\subsection{Permeability index (PI)}

A modified criterion has been evolved based on the solubility of salts and the reaction occurring in the soil solution from cation exchange for estimating the quality of agricultural waters (Gupta and Gupta 1987). The soil permeability of an area eventually decreases due to continuous irrigational practices and is defined based on quantity of bicarbonate, sodium, calcium and magnesium in water. Doneen (1964) had empirically developed a term called, 'Permeability Index' after conducting a series of experiments for which he had used a large number of irrigation waters varying in ionic relationships and concentration. The permeability index is calculated by the following formula:

$$
\mathrm{PI}=\frac{\left(\mathrm{Na}^{+}+\mathrm{HCO}_{3}^{-}\right) \times 100}{\left(\mathrm{Ca}^{2+}+\mathrm{Mg}^{2+}+\mathrm{Na}^{+}\right)}
$$

where concentrations of all ions have been expressed in meq/L.

Permeability index varies from 23.07 (at Khatangadi) to 90.06 (at Aamgachi) in post-monsoon and from 18.20 (at Bhagabanbati) to 66.09 (at Abdarpur) in pre-monsoon. PI is classified under Class I ( $>75 \%$ permeability), Class II $(25-75 \%$ permeability) and Class III ( $<75 \%$ permeability) orders. Class I and Class II water are categorized as good for irrigation and Class III water is unsuitable with $25 \%$ of maximum permeability. Doneen (1964) had prepared a chart to classify water based on its permeability index (defined by equation 3 ) value and according to Doneen's chart (figure 15), all water samples of the study area fall under Class I and II during both post- and pre-monsoon; which indicates overall the water is moderately good for irrigation.

\subsection{Residual sodium carbonate (RSC)}

Residual sodium carbonate (RSC) index of irrigation/soil water is used to indicate the alkalinity 
Table 1. Physico-chemical analysis results for both post- and pre-monsoon sessions.

\begin{tabular}{|c|c|c|c|c|c|c|c|c|c|c|c|c|c|c|c|c|c|c|c|c|c|c|c|c|c|c|c|}
\hline \multirow{2}{*}{$\begin{array}{l}\text { Location } \\
\text { no. }\end{array}$} & \multicolumn{2}{|c|}{$\mathrm{pH}$} & \multicolumn{2}{|c|}{ TDS } & \multicolumn{2}{|c|}{$\mathrm{EC}$} & \multicolumn{2}{|c|}{ TA } & \multicolumn{2}{|c|}{$\mathrm{TH}$} & $\mathrm{Ca}^{2+}$ & \multicolumn{2}{|c|}{$\mathrm{Mg}^{2+}$} & \multicolumn{2}{|c|}{$\mathrm{Na}^{+}$} & \multicolumn{2}{|c|}{$\mathrm{K}^{+}$} & \multicolumn{2}{|c|}{$\mathrm{Fe}^{2+}$} & \multicolumn{2}{|c|}{$\mathrm{CO}_{3}^{2-}$} & \multicolumn{2}{|c|}{$\mathrm{HCO}_{3}^{-}$} & \multicolumn{2}{|c|}{$\mathrm{Cl}^{-}$} & \multicolumn{2}{|c|}{$\mathrm{SO}_{4}^{2-}$} \\
\hline & Post & Pre & Post & Pre & Post & Pre & Post & Pre & Post & Pre & $\overline{\text { Post Pre }}$ & Post & Pre & Post & Pre & Post & Pre & Post & Pre & Post & Pre & Post & Pre & Post & Pre & Post & Pre \\
\hline L1 & 8.1 & 8.4 & 74.0 & 150.0 & 90.0 & 55.0 & 120.0 & 40.0 & 80.0 & 48.0 & $12.6 \quad 6.7$ & 11.8 & 7.6 & 8.7 & 9.0 & 1.0 & 0.2 & 0 & 0.01 & 0.0 & 0.0 & 146.4 & 48.8 & 24.9 & 15.0 & 0.7 & 0.5 \\
\hline AL2 & 7.8 & 7.3 & 82.0 & 180.0 & 110.0 & 83.0 & 50.0 & 60.0 & 55.0 & 72.0 & 16.815 .1 & 3.2 & 8.3 & 123 & 14.0 & 1.0 & 0.28 & 0.05 & 0.04 & 0.0 & 0.0 & 61.0 & 73.2 & 29.9 & 30.0 & 2.8 & 2.8 \\
\hline AL3 & 7.1 & 6.6 & 622.0 & 1200.0 & 190.0 & 590.0 & 650.0 & 140.0 & 365.0 & 244.0 & 109.257 .1 & 22.5 & 24.7 & 53.3 & 66.0 & 3.0 & 0.76 & 0.0 & 0.01 & 0.0 & 0.0 & 793.0 & 170.8 & 129.9 & 179.9 & 48.8 & 45.7 \\
\hline $\mathrm{L} 4$ & 7.6 & 7.3 & 225.0 & 510.0 & 191.0 & 227.0 & 670.0 & 180.0 & 200.0 & 124.0 & 58.823 .5 & 12.9 & 15.9 & 24.7 & 28.0 & 1.3 & 0.32 & 0.05 & 0.16 & 72.0 & 12.0 & 671.0 & 195.2 & 24.9 & 15.0 & 1.8 & 1.9 \\
\hline L5 & 7.7 & 7.4 & 266.0 & 600. & 200.0 & 277.0 & 600. & 190. & 240. & 180.0 & 46.220 .2 & 30.4 & 31.6 & 10.0 & 13.0 & 1.7 & 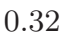 & 0.03 & 0.00 & 0.0 & 12.0 & 732.0 & 207.4 & 15.0 & 25.0 & 1.2 & 1.4 \\
\hline L6 & 7.8 & 7.2 & 325.0 & 720.0 & 210.0 & 333.0 & 880.0 & 230 . & 250.0 & 160.0 & 54.616 .8 & 27.7 & 28.8 & 29.3 & 40.0 & 4.0 & .08 & 0.07 & 0.15 & 0.0 & 0.0 & 1073.6 & 80.6 & 15.0 & 15.0 & 6.1 & 6.6 \\
\hline L7 & 8.0 & 7.4 & 294.0 & 690 & 220.0 & 309 & 6 & 240 & 200.0 & 152.0 & 37.818 .5 & 25.7 & 25.8 & 11.7 & 51.0 & 4.7 & 1.2 & 0.04 & 0.20 & 48.0 & 0.0 & 658.8 & 292.8 & 34.9 & 40.0 & 7.6 & 10.4 \\
\hline AL8 & 7.0 & 7.1 & 182.0 & 420.0 & 190.0 & 182.0 & 550.0 & 180.0 & 180.0 & 156.0 & 46.233 .6 & 15.7 & 17.6 & 14.7 & 18.0 & 0.7 & 0.24 & 0.03 & 0.20 & 36.0 & 12.0 & 597.8 & 195.2 & 15.0 & 20.0 & 1.7 & 1.2 \\
\hline L9 & 7.8 & 7.4 & 306.0 & 750. & 240.0 & 317 & 80 & 24 & 210.0 & 132.0 & 42.018 .5 & 25.6 & 20.9 & 58.3 & 64.0 & 5.3 & 3 & 0.0 & 0.11 & 180.0 & 0.0 & 610. & 92.8 & 39.9 & 35.0 & 15.9 & 15.6 \\
\hline AL10 & 7.1 & 7.1 & 280.0 & 710.0 & 210.0 & 316.0 & 560.0 & 140.0 & 290.0 & 208.0 & 79.838 .6 & 22.1 & 27.2 & 7.0 & 8.0 & 1.7 & 0.36 & 0.06 & 0.10 & 0.0 & 0.0 & 683.2 & 170.8 & 79.9 & 75.0 & 0.8 & 0.6 \\
\hline L11 & 7.4 & 7.0 & 247.0 & 580 . & 220.0 & 256.0 & 670. & 250 & 210.0 & 180.0 & 46.245 .4 & 23.1 & 16.3 & 41.7 & 44.0 & 4.3 & & 0.02 & 0.05 & 84.0 & 36.0 & 646.6 & 231.8 & 34.9 & 35.0 & 6.2 & 4.3 \\
\hline AL12 & 7.4 & 6.9 & 196.0 & 470.0 & 200.0 & 203.0 & 540.0 & 160.0 & 200.0 & 140.0 & 37.820 .2 & 25.7 & 21.9 & 19.7 & 19.0 & 1.0 & 0.24 & 0.02 & 0.16 & 12.0 & 12.0 & 634.4 & 170.8 & 15.0 & 15.0 & 1.5 & 0.7 \\
\hline L13 & 7.2 & 6.6 & 309.0 & 1150.0 & 240.0 & 552.0 & 370.0 & 120.0 & 280.0 & 384.0 & 71.495 .8 & 24.8 & 35.3 & 24.0 & 37.0 & 1.0 & 0.28 & 1.81 & 6.06 & 0.0 & 0.0 & 451.4 & 146.4 & 34.9 & 274.9 & 3.6 & 8.0 \\
\hline AL14 & 8.4 & 7.5 & 250.0 & 550 . & 250.0 & 248. & 790. & 250 . & 140.0 & 76.0 & 21.011 .8 & 21.4 & 11.4 & 56.7 & 69.0 & 3.0 & 0.8 & 0.16 & 0.27 & 180.0 & 24.0 & 597. & 256.2 & 34.9 & 20.0 & 0.6 & 1.1 \\
\hline AL15 & 7.6 & 6.8 & 202.0 & 420.0 & 190.0 & 148.0 & 430.0 & 150.0 & 200.0 & 124.0 & 33.630 .2 & 28.3 & 11.8 & 24.7 & 23.0 & 0.7 & 0.2 & 0.01 & 2.01 & 0.0 & 24.0 & 524.6 & 134.2 & 24.9 & 25.0 & 0.4 & 2.1 \\
\hline L16 & 7.6 & 7.6 & 111.0 & 280 & 160.0 & 115 & $2 \pi$ & 130 & 160. & 104.0 & 29.428 .6 & 21.11 & 8.0 & 10.3 & 13.0 & 0.7 & .32 & 0. & 0.06 & 0.0 & 0.0 & 329.4 & 158.6 & 15.0 & 20.0 & 0.7 & 0.1 \\
\hline AL17 & 7.6 & 6.9 & 188.0 & 420.0 & 230.0 & 194.0 & 620.0 & 180.0 & 160.0 & 96.0 & 37.821 .8 & 15.9 & 10.1 & 317 & 33.0 & 1.0 & 0.2 & 0.08 & 0.25 & 204.0 & 12.0 & 341.6 & 195.2 & 19.9 & 15.0 & 4.1 & 2.5 \\
\hline L18 & 7.6 & 7.8 & 203.0 & 420 & 210.0 & 181 & & & 16 & 140.0 & 42.02 & 13.4 & 16.7 & 18.3 & 22.0 & 3.0 & & & & 204.0 & 12.0 & 48.8 & 4.2 & 29.9 & 40.0 & 2.1 & 6.7 \\
\hline AL19 & 7.1 & 6.4 & 344.0 & 790.0 & 300.0 & 353.0 & 670. & 140 & 260.0 & 184.0 & 71.445 .4 & 19.9 & 17.2 & 41.7 & 48.0 & 10.0 & 2.48 & 0.01 & 0.50 & 156.0 & 0.0 & 500.2 & 170.8 & 64.9 & 105.0 & 37.9 & 41.4 \\
\hline AL20 & 7.2 & 6.7 & 355.0 & 480 . & 299.0 & 219.0 & 420.0 & 130 & 240.0 & 160.0 & 54.633 .6 & 25.3 & 18.5 & 46.7 & 21.0 & 2.7 & 0.36 & 0.11 & 0.63 & 24.0 & 0.0 & 463.6 & 158.6 & 124.9 & 50.0 & 39.6 & 5.7 \\
\hline AL21 & 7.6 & 7.0 & 229.0 & 510. & 240.0 & 224.0 & 510. & 150 & 200.0 & 108.0 & 37.820 .2 & 25.7 & 14.1 & 28.0 & 31.0 & 1.3 & 0.28 & 0.02 & 0.06 & 0.0 & 0.0 & 622.2 & 183.0 & 29.9 & 30.0 & 3.5 & 2.0 \\
\hline AL22 & 7.8 & 6.9 & 119.0 & 250.0 & 170.0 & 113.0 & 350.0 & 100.0 & 120.0 & 92.0 & 25.223 .5 & 13.9 & 8.1 & 12.3 & 12.0 & 2.0 & 0.2 & 0.02 & 0.18 & 0.0 & 0.0 & 427.0 & 122.0 & 19.9 & 25.0 & 2.3 & 2.1 \\
\hline AL23 & 7.7 & 7.6 & 143.0 & 230.0 & 190.0 & 102.0 & 490.0 & 60.0 & 140.0 & 80.0 & 33.616 .8 & 13.7 & 9.3 & 17.3 & 16.0 & 2.0 & 0.16 & 0.08 & 0.25 & 36.0 & 0.0 & 524.6 & 73.2 & 39.9 & 35.0 & 1.9 & 1.8 \\
\hline AL24 & 7.4 & 6.9 & 280.0 & 650.0 & 270.0 & 286.0 & 620.0 & 90.0 & 280.0 & 120.0 & 58.816 .8 & 32.5 & 19.0 & 34.0 & 38.0 & 1.3 & 0.36 & 0.01 & 0.01 & 60.0 & 0.0 & 634.4 & 109.8 & 29.9 & 30.0 & 4.1 & 3.5 \\
\hline AL25 & 7.5 & 7.1 & 264.0 & 600. & 260.0 & 270.0 & 800.0 & 320 . & 260.0 & 152.0 & 63.021 .8 & 25.0 & 23.8 & 24.7 & 31.0 & 1.3 & 0.28 & 0.0 & 0.28 & 180.0 & 0.0 & 610.0 & 390.4 & 19.9 & 20.0 & 1.2 & 1.5 \\
\hline AL26 & 7.1 & 6.8 & 256.0 & 730.0 & 251.0 & 322.0 & 350.0 & 130. & 300.0 & 240.0 & 50.452 .1 & 42.5 & 26.8 & 15.3 & 25.0 & 3.7 & 1.12 & 0.02 & 0.11 & 0.0 & 0.0 & 427.0 & 58.6 & 74.9 & 85.0 & 22.1 & 56.7 \\
\hline Min. & 7.0 & 6.4 & 74.0 & 55.0 & 90.0 & 150.0 & 50.0 & 40.0 & 55.0 & 48.0 & $12.6 \quad 6.7$ & 3.2 & 7.6 & 7.0 & 8.0 & 0.7 & 0 . & 0.0 & 0.0 & 0.0 & 0.0 & 48.8 & 48.8 & 15.0 & 15.0 & 0.43 & 0.1 \\
\hline Max. & 8.4 & 8.4 & 622.0 & 590.0 & 300.0 & 1200.0 & 880.0 & 320.0 & 365.0 & 384.0 & 109.295 .8 & 42.5 & 35.3 & 58.3 & 69.0 & 10.0 & 2.5 & 1.8 & 6.1 & 204.0 & 36.0 & 1073.6 & 390.4 & 129.9 & 274.9 & 48.8 & 56.7 \\
\hline Mean & 7.5 & 7.1 & 244.3 & 556.1 & 212.7 & 249.0 & 530.0 & 158.8 & 206.9 & 148.3 & 46.829 .3 & 21.9 & 18.3 & 26.04 & 30.5 & 2.4 & 0.6 & 0.12 & 0.47 & 56.8 & 6.0 & 531.2 & 181.6 & 39.4 & 49.0 & 8.4 & 8.7 \\
\hline Median & 7.6 & 7.1 & 248.5 & 530.0 & 210.0 & 237.5 & 555.0 & 145.0 & 200.0 & 140.0 & 44.122 .7 & 22.8 & 17.4 & 24.3 & 26.5 & 1.7 & 0.3 & 0.03 & 0.16 & 18.0 & 0.0 & 597.8 & 170.8 & 30.0 & 30.0 & 2.6 & 2.3 \\
\hline Std. dvn & 0.34 & 0.43 & 109.2 & 125.9 & 48.65 & 256.6 & 204.2 & 66.7 & 70.5 & 68.7 & 21.118 .4 & 8.0 & 7.9 & 15.4 & 17.8 & 2.1 & 0.54 & 0.35 & 1.21 & 75.5 & 9.75 & 222.6 & 76.2 & 31.15 & 58.65 & 13.43 & 15.03 \\
\hline
\end{tabular}

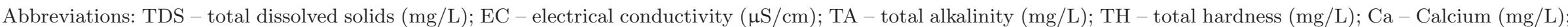

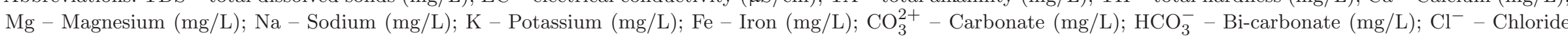
$(\mathrm{mg} / \mathrm{L}) ; \mathrm{SO}_{4}^{2-}-$ Sulfate $(\mathrm{mg} / \mathrm{L})$. 
Table 2. Values of calculated water quality parameters/indices.

\begin{tabular}{|c|c|c|c|c|c|c|c|c|c|c|c|c|c|}
\hline \multirow{2}{*}{$\begin{array}{l}\text { Location } \\
\text { no. }\end{array}$} & \multirow{2}{*}{$\begin{array}{l}\text { Location } \\
\text { name }\end{array}$} & \multicolumn{2}{|c|}{ SAR } & \multicolumn{2}{|c|}{ SSP } & \multicolumn{2}{|c|}{$\mathrm{PI}$} & \multicolumn{2}{|c|}{$\mathrm{RSC}$} & \multicolumn{2}{|c|}{ MAR } & \multicolumn{2}{|c|}{$\mathrm{KR}$} \\
\hline & & Post & Pre & Post & Pre & Post & Pre & Post & Pre & Post & Pre & Post & Pre \\
\hline AL1 & Abdarpur & 0.42 & 0.56 & 19.94 & 29.01 & 78.12 & 66.09 & 0.78 & 0.46 & 61.01 & 65.37 & 0.23 & 0.40 \\
\hline AL2 & Singur & 0.72 & 0.71 & 33.72 & 29.80 & 61.50 & 53.79 & -0.10 & 0.44 & 23.92 & 47.90 & 0.49 & 0.42 \\
\hline AL3 & Kochujor & 1.21 & 1.83 & 24.63 & 37.03 & 39.68 & 24.37 & 5.67 & -0.06 & 25.52 & 41.87 & 0.32 & 0.58 \\
\hline AL4 & Lalmohanpur & 0.76 & 1.09 & 21.60 & 32.88 & 66.23 & 49.31 & 9.38 & 2.02 & 26.82 & 52.99 & 0.27 & 0.49 \\
\hline AL5 & Bonsonka & 0.28 & 0.42 & 8.98 & 13.60 & 66.09 & 44.38 & 7.16 & 2.39 & 52.29 & 72.33 & 0.09 & 0.16 \\
\hline AL6 & Talibpur & 0.80 & 1.37 & 21.48 & 35.29 & 67.73 & 44.82 & 12.56 & 3.76 & 45.81 & 74.07 & 0.25 & 0.54 \\
\hline AL7 & Kubirpur & 0.36 & 1.79 & 13.45 & 42.25 & 72.86 & 43.61 & 8.37 & 3.88 & 53.16 & 69.96 & 0.13 & 0.72 \\
\hline AL8 & Abinashpur & 0.47 & 0.62 & 15.31 & 20.06 & 74.13 & 46.34 & 7.38 & 1.52 & 36.22 & 46.57 & 0.18 & 0.25 \\
\hline AL9 & Piasala More & 1.74 & 2.41 & 38.69 & 51.34 & 49.24 & 42.97 & 11.77 & 3.88 & 50.41 & 65.38 & 0.60 & 1.04 \\
\hline AL10 & Purandarpur & 0.18 & 0.24 & 5.62 & 7.84 & 54.86 & 37.17 & 5.37 & 0.87 & 31.56 & 53.97 & 0.05 & 0.08 \\
\hline AL11 & Gangta & 1.25 & 1.42 & 31.24 & 34.92 & 55.69 & 37.13 & 9.17 & 1.53 & 45.41 & 37.39 & 0.43 & 0.53 \\
\hline AL12 & Majhigram & 0.60 & 0.69 & 17.92 & 22.73 & 66.80 & 46.60 & 6.77 & 1.79 & 53.16 & 64.38 & 0.21 & 0.29 \\
\hline AL13 & Bhaganbati & 0.62 & 0.82 & 15.95 & 17.29 & 41.78 & 18.20 & 1.77 & -2.39 & 36.64 & 38.04 & 0.19 & 0.21 \\
\hline AL14 & Dhalla & 2.07 & 3.42 & 47.31 & 66.30 & 61.61 & 48.19 & 12.97 & 3.61 & 62.89 & 61.71 & 0.87 & 1.95 \\
\hline AL15 & Saktipur & 0.75 & 0.90 & 21.25 & 28.71 & 58.45 & 43.42 & 4.56 & 0.69 & 58.40 & 39.43 & 0.27 & 0.40 \\
\hline AL16 & Ajaypur & 0.35 & 0.55 & 12.62 & 21.53 & 63.62 & 61.28 & 2.17 & 1.17 & 54.48 & 31.69 & 0.14 & 0.27 \\
\hline AL17 & Joka & 1.08 & 1.46 & 30.33 & 42.68 & 52.84 & 54.54 & 9.18 & 2.11 & 41.33 & 43.53 & 0.43 & 0.74 \\
\hline AL18 & Khatangadi & 0.63 & 0.81 & 21.36 & 25.67 & 23.07 & 40.20 & 4.38 & 0.77 & 34.75 & 49.42 & 0.25 & 0.34 \\
\hline AL19 & Kendulia & 1.12 & 1.53 & 28.35 & 36.73 & 42.49 & 30.98 & 8.17 & 0.53 & 31.71 & 38.77 & 0.35 & 0.56 \\
\hline AL20 & Lataboni & 1.31 & 0.72 & 30.26 & 22.24 & 42.20 & 39.88 & 3.57 & 0.92 & 43.53 & 47.91 & 0.42 & 0.28 \\
\hline AL21 & Nabagram & 0.86 & 1.29 & 23.67 & 38.34 & 62.02 & 50.46 & 6.17 & 1.99 & 53.16 & 53.74 & 0.30 & 0.62 \\
\hline AL22 & Aamgachi & 0.49 & 0.54 & 19.54 & 22.19 & 90.06 & 60.12 & 4.58 & 0.82 & 47.92 & 36.47 & 0.22 & 0.28 \\
\hline AL23 & Gobindopur & 0.63 & 0.77 & 22.21 & 30.26 & 82.85 & 48.16 & 6.98 & 0.36 & 40.39 & 47.91 & 0.27 & 0.43 \\
\hline AL24 & Agar & 0.88 & 1.50 & 21.13 & 40.65 & 46.76 & 34.55 & 6.76 & 0.96 & 47.91 & 65.37 & 0.26 & 0.68 \\
\hline AL25 & Ekdala More & 0.66 & 1.09 & 17.45 & 30.60 & 51.21 & 58.58 & 10.77 & 5.31 & 39.82 & 64.46 & 0.20 & 0.44 \\
\hline AL26 & Suri Town & 0.38 & 0.70 & 11.16 & 18.74 & 40.01 & 28.31 & 0.94 & 0.00 & 58.40 & 46.16 & 0.11 & 0.22 \\
\hline & Min. & 0.18 & 0.24 & 5.62 & 7.84 & 23.07 & 18.20 & -0.10 & -2.39 & 23.92 & 31.69 & 0.05 & 0.08 \\
\hline & Max. & 2.07 & 3.42 & 47.31 & 66.30 & 90.06 & 66.09 & 12.97 & 5.31 & 62.89 & 74.07 & 0.87 & 1.95 \\
\hline & Mean & 0.79 & 1.13 & 22.12 & 30.72 & 58.15 & 44.36 & 6.43 & 1.51 & 44.49 & 52.18 & 0.29 & 0.50 \\
\hline & Median & 0.69 & 1.42 & 21.31 & 30.03 & 59.98 & 44.60 & 6.77 & 1.07 & 45.61 & 48.67 & 0.26 & 0.43 \\
\hline & Std. dvn & 0.45 & 0.69 & 9.33 & 12.37 & 15.27 & 11.42 & 3.61 & 1.60 & 11.21 & 12.42 & 0.17 & 0.36 \\
\hline
\end{tabular}

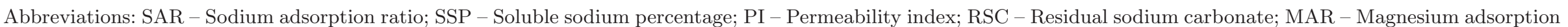
ratio; KR - Kelly's ratio. 
Table 3. Classification of samples according to standards specified for different water quality parameters.

\begin{tabular}{|c|c|c|c|c|c|c|}
\hline \multirow{2}{*}{ Parameters } & \multirow[b]{2}{*}{ Range } & \multirow[b]{2}{*}{ Class } & \multicolumn{2}{|c|}{ No. of samples } & \multicolumn{2}{|c|}{ Percentage of samples } \\
\hline & & & Post-monsoon & Pre-monsoon & Post-monsoon & Pre-monsoon \\
\hline \multirow[t]{5}{*}{ SAR } & $<20$ & Excellent & 26 & 26 & 100 & 100 \\
\hline & $20-40$ & Good & 0 & 0 & 0 & 0 \\
\hline & $40-60$ & Permissible & 0 & 0 & 0 & 0 \\
\hline & $60-80$ & Doubtful & 0 & 0 & 0 & 0 \\
\hline & $>80$ & Unsafe & 0 & 0 & 0 & 0 \\
\hline \multirow{5}{*}{ EC WHO (2008) } & $<250$ & Excellent & 20 & 14 & 77 & 54 \\
\hline & $250-750$ & Good & 6 & 12 & 23 & 46 \\
\hline & $750-2000$ & Permissible & 0 & 0 & 0 & 0 \\
\hline & $2000-3000$ & Doubtful & 0 & 0 & 0 & 0 \\
\hline & $>3000$ & Unsuitable & 0 & 0 & 0 & 0 \\
\hline \multirow[t]{4}{*}{ TH (Sawyer and McCarty 1967) } & $<75$ & Soft & 1 & 2 & 4 & 8 \\
\hline & $75-150$ & Moderate & 4 & 12 & 15 & 46 \\
\hline & $150-300$ & Hard & 19 & 11 & 73 & 42 \\
\hline & $>300$ & Very hard & 2 & 1 & 8 & 4 \\
\hline \multirow[t]{3}{*}{$\mathrm{RSC}$} & $<1.25$ & Safe & 16 & 14 & 61 & 54 \\
\hline & $1.25-2.50$ & Marginally suitable & 9 & 7 & 35 & 27 \\
\hline & $>2.50$ & Unsuitable & 1 & 5 & 4 & 19 \\
\hline \multirow[t]{2}{*}{ MAR } & $<50$ & Suitable & 19 & 14 & 73 & 54 \\
\hline & $>50$ & Unsuitable & 7 & 12 & 27 & 46 \\
\hline \multirow[t]{2}{*}{ SSP } & 200 & Suitable & 26 & 26 & 100 & 100 \\
\hline & $>200$ & Unsuitable & 0 & 0 & 0 & 0 \\
\hline \multirow[t]{2}{*}{$\mathrm{KR}$} & $<1.0$ & Suitable & 26 & 24 & 100 & 92 \\
\hline & $>1.0$ & Unsuitable & 0 & 2 & 0 & 8 \\
\hline \multirow[t]{3}{*}{$\mathrm{PI}$} & $<80$ & Good & 26 & 26 & 100 & 100 \\
\hline & $80-100$ & Moderate & 0 & 0 & 0 & 0 \\
\hline & $100-120$ & Poor & 0 & 0 & 0 & 0 \\
\hline \multirow[t]{5}{*}{ WQI } & $0-25$ & Excellent & 19 & 8 & 73 & 31 \\
\hline & $26-50$ & Good & 4 & 8 & 15 & 31 \\
\hline & $51-75$ & Poor & 2 & 3 & 8 & 12 \\
\hline & $76-100$ & Very Poor & - & 4 & - & 15 \\
\hline & $>100$ & Unfit for drinking & 1 & 3 & 4 & 11 \\
\hline
\end{tabular}

hazard of soil. RSC index is used to find the suitability of water for irrigation in clay soils which has high cation exchange capacity. When dissolved sodium in comparison with dissolved calcium and magnesium is high in water, clay soil swells or undergoes dispersion which drastically reduces its infiltration capacity. The residual sodium carbonate index (defined by equation 4) of water/soil signifies the alkalinity hazard posed by it and it finds the suitability of water for irrigation in case of clay soils (Raghunath 1987).

$$
\mathrm{RSC}=\left(\mathrm{HCO}_{3}^{-}+\mathrm{CO}_{3}^{2-}\right)-\left(\mathrm{Ca}^{2+}+\mathrm{Mg}^{2+}\right)
$$

where concentrations of all ions have been expressed in meq/L.

Residual sodium carbonate values should be preferably $<1.25$ to be rendered suitable for irrigation purposes and hence, in the present study where RSC values range between -0.10 and 12.97 and $>80 \%$ of the water samples have RSC $>2.5$ (figure 16a and b); it can be concluded that water in this area poses an alkaline hazard to the soil during post-monsoon period. In the pre-monsoon period, $76 \%$ of RSC values fall in the safe category, indicating localised hazard.

\subsection{Magnesium adsorption ratio (MAR)}

Generally in most groundwaters, $\mathrm{Ca}^{2+}$ and $\mathrm{Mg}^{2+}$ maintain a state of equilibrium (Hem 1985). During equilibrium, more $\mathrm{Mg}^{2+}$ in groundwater adversely affects the soil quality rendering it alkaline which result in decrease of crop yield (Kumar et al. 2007). Paliwal (1972) developed an index for calculating the magnesium hazard called magnesium adsorption ratio (MAR). Magnesium adsorption ratio (defined by equation 5 ) indicates the magnesium hazard that can be caused when magnesium remains in equilibrium in groundwater. This index was devised by Paliwal (1972) where the calcium and magnesium ratios are taken into consideration, 


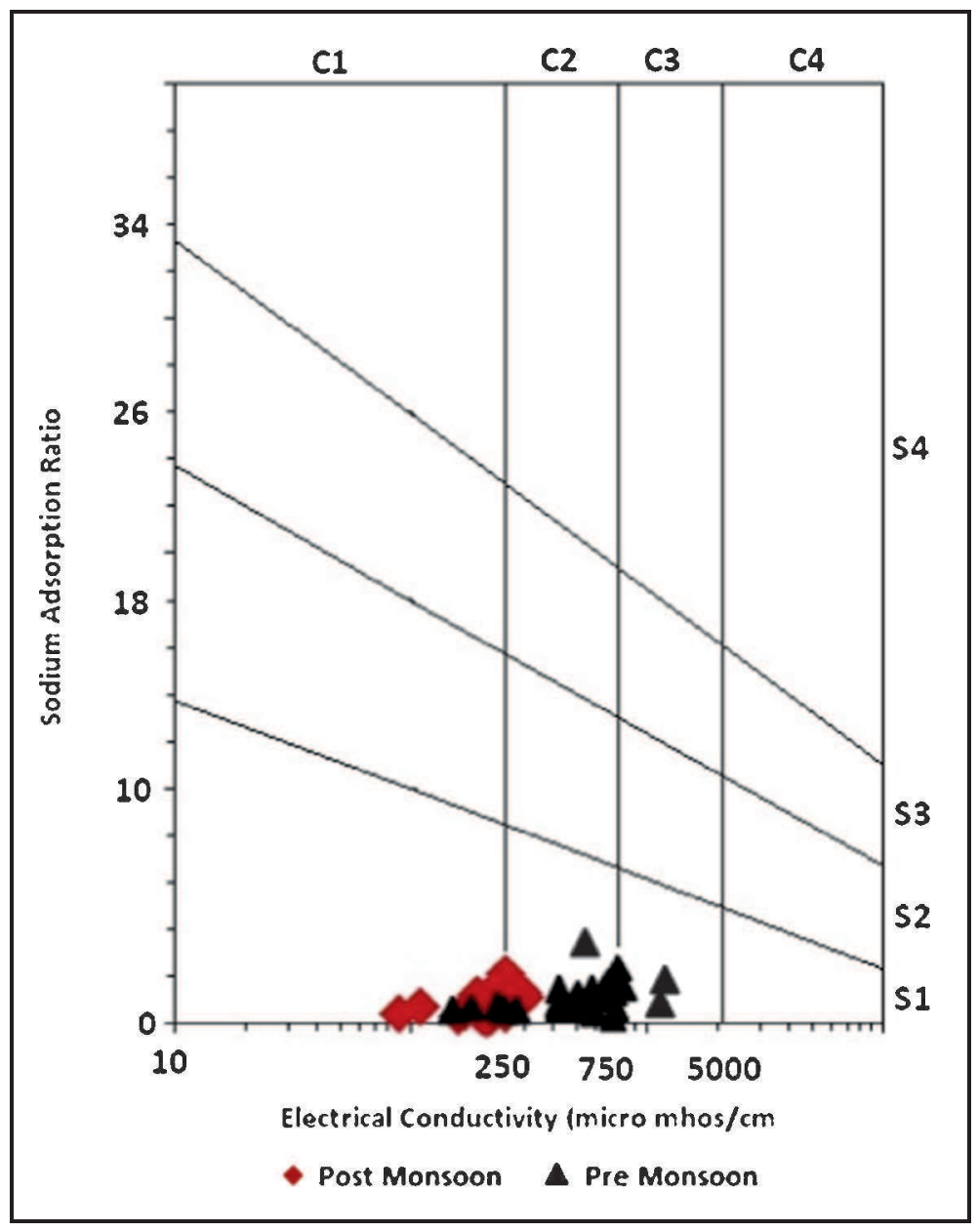

Figure 13. US salinity diagram (post- and pre-monsoon).

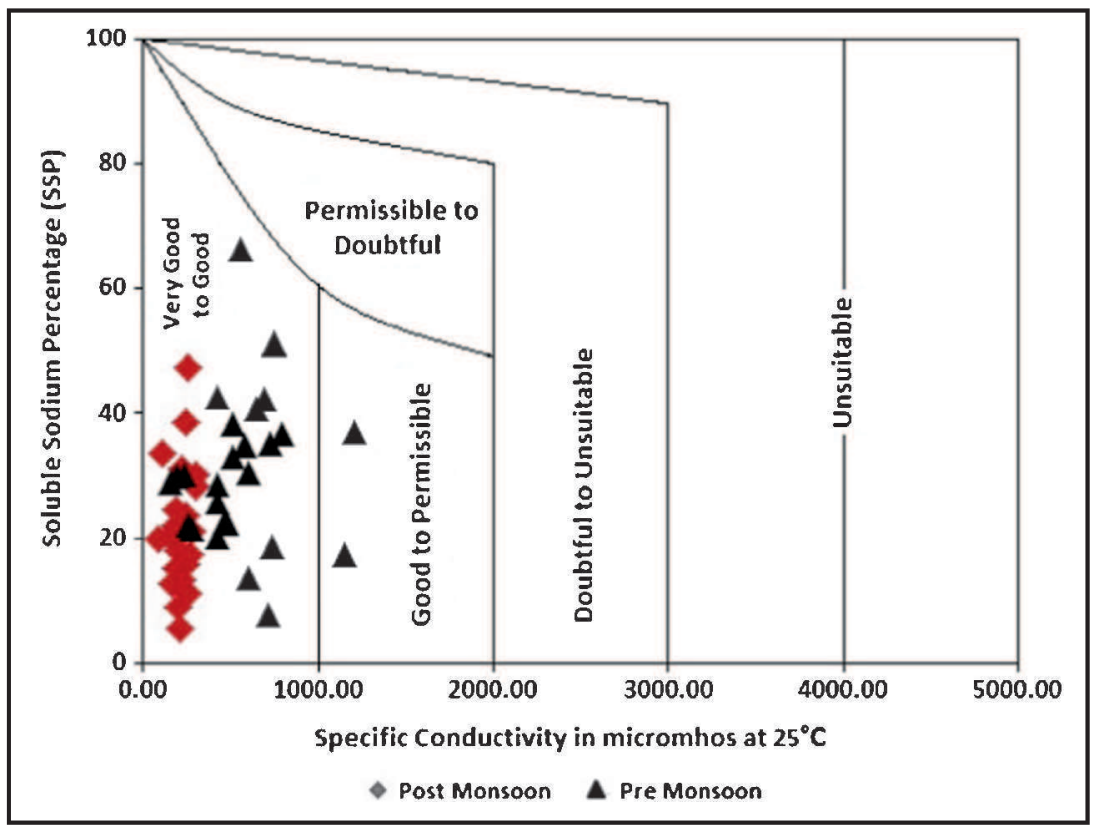

Figure 14. Wilcox diagram (post- and pre-monsoon). 


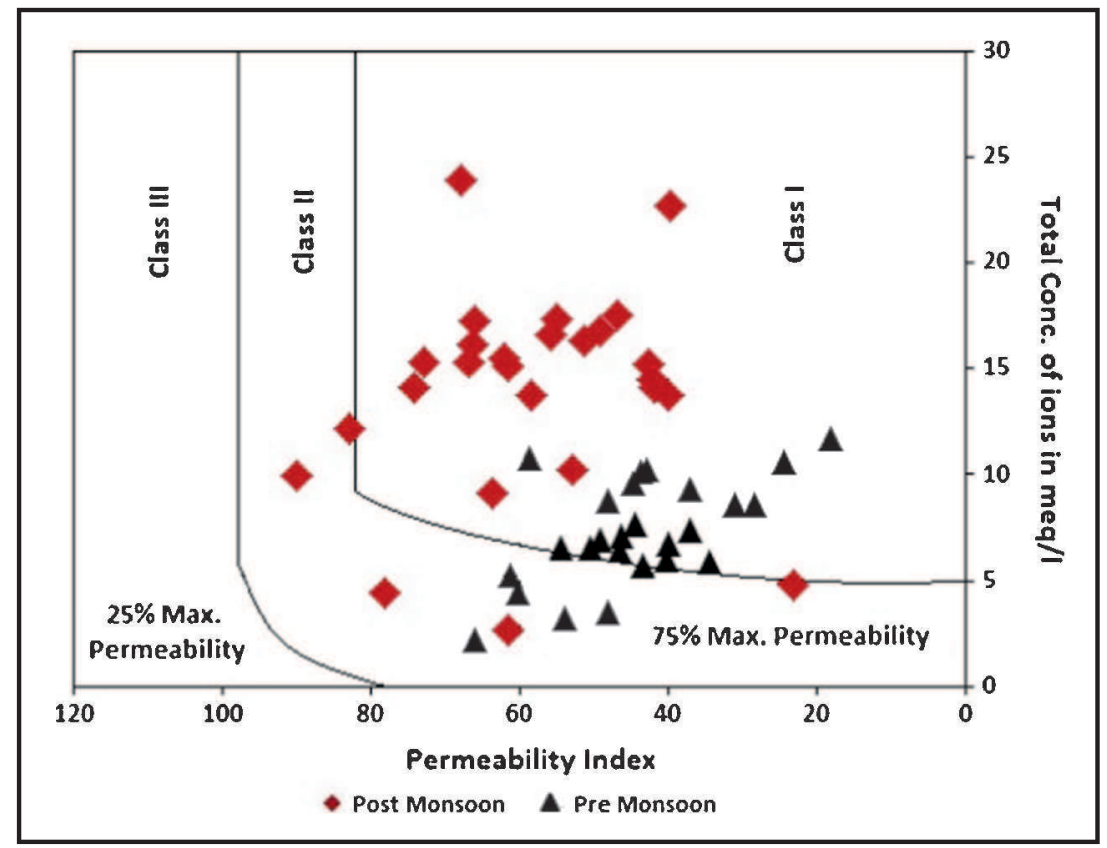

Figure 15. Doneen's chart (post- and pre-monsoon).

as mostly calcium and magnesium maintain equilibrium in water (Hem 1985; Giggenbach 1988).

$$
\mathrm{MAR}=\left(\mathrm{Mg}^{2+} * 100\right) /\left(\mathrm{Ca}^{2+}+\mathrm{Mg}^{2+}\right)
$$

where concentrations of all ions have been expressed in meq/L.

MAR categorizes water into two broad classes water having MAR $<50$ is considered suitable for irrigation whereas water with MAR $>50$ is considered unsuitable, based on which it can be concluded that almost two-thirds of the water samples are suitable for irrigation in post-monsoon. During pre-monsoon MAR values change rendering about half of the samples suitable for irrigation (figure $17 \mathrm{a}$ and $\mathrm{b}$ ).

\subsection{Kelly's ratio (KR)}

Classification of groundwater quality for irrigation is also done based on Kelly's (1963) ratio. Kelly's ratio (defined by equation 6) is measured considering sodium ion concentration against calcium and magnesium ion concentrations. Kelly's ratio of more than 1 indicates an excess level of $\mathrm{Na}^{+}$ in water. Water with a value of $\mathrm{KR}<1$ is considered suitable for irrigation, while those with a ratio more than 3 is considered as unsuitable for irrigation (Ramesh and Elango 2012). It is defined as:

$$
\mathrm{KR}=\mathrm{Na}^{2+} /\left(\mathrm{Ca}^{2+}+\mathrm{Mg}^{2+}\right)
$$

where concentrations of all ions have been expressed in meq/L.
During post-monsoon, KR values vary between 0.05 and 0.87 and during pre-monsoon, the values vary between 0.08 and 1.95. According to Kelly's ratio water analyzed is suitable for irrigation during both periods barring two locations in pre-monsoon.

\subsection{Water quality for drinking purposes}

In large and specially semi-urban or rural parts of our country, groundwater sources in the form of dug wells or borewells are the only source of drinking water. In the present study, to ascertain whether or not the water consumed by villagers meet the drinking water standards, the total hardness of samples have been measured and the use of hydrogeochemical facies (Piper diagram) and water quality index have been made.

\subsection{Total hardness}

Water hardness has no known adverse effects; however, some evidence indicates its role in heart disease (WHO 2008). Hard water is unsuitable for domestic use and it is a measure of the $\mathrm{Ca}^{2+}$ and $\mathrm{Mg}^{2+}$ content expressed in equivalent of calcium carbonate. Hardness of water (temporary and permanent) is by the inhibition of soap action in water due to the precipitation of $\mathrm{Ca}^{2+}$ and $\mathrm{Mg}^{2+}$ salts like carbonates, sulphates and chlorides. Temporary hardness is mainly due to the presence of calcium carbonate and gets removed when water is 


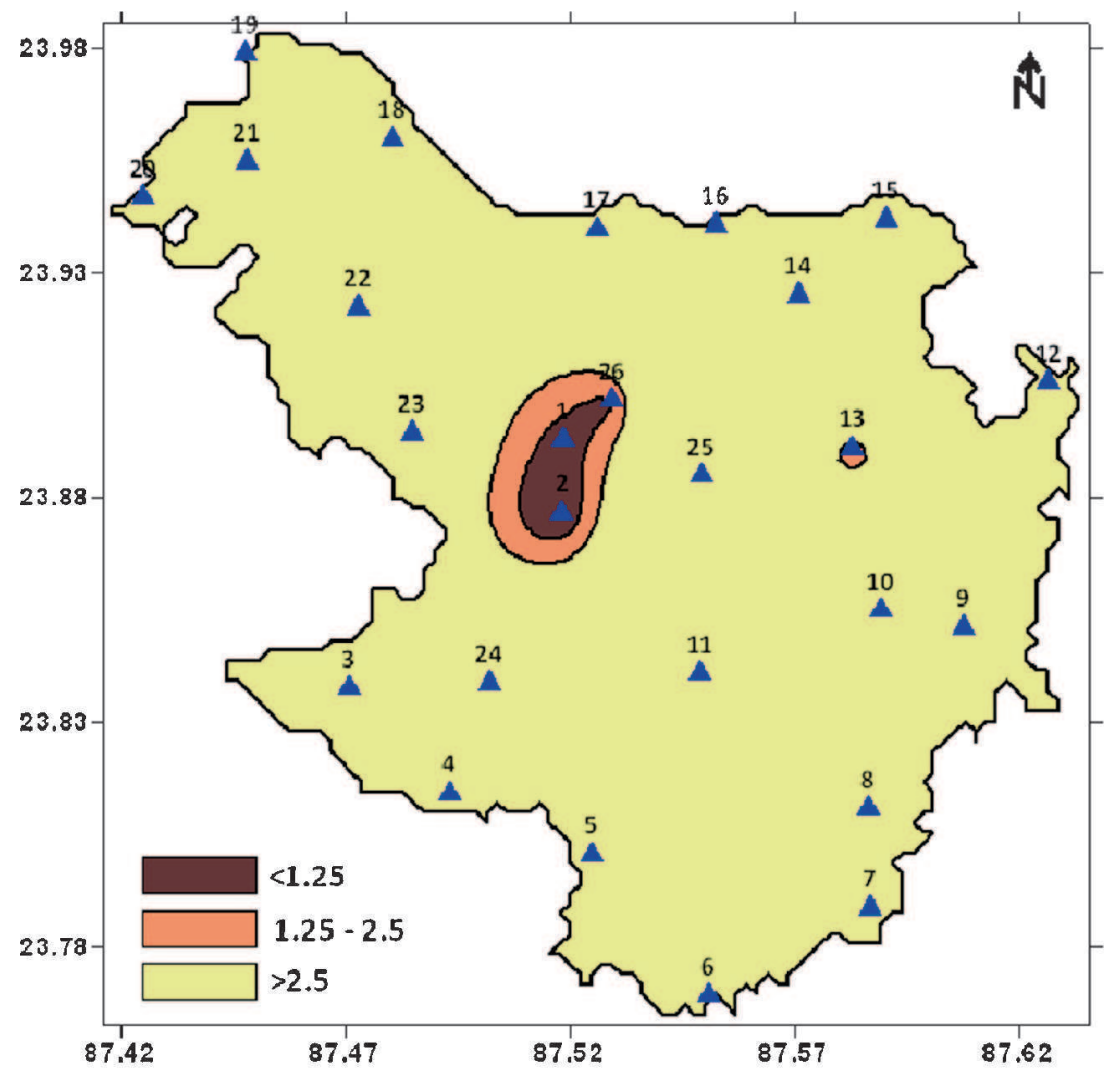

(a)

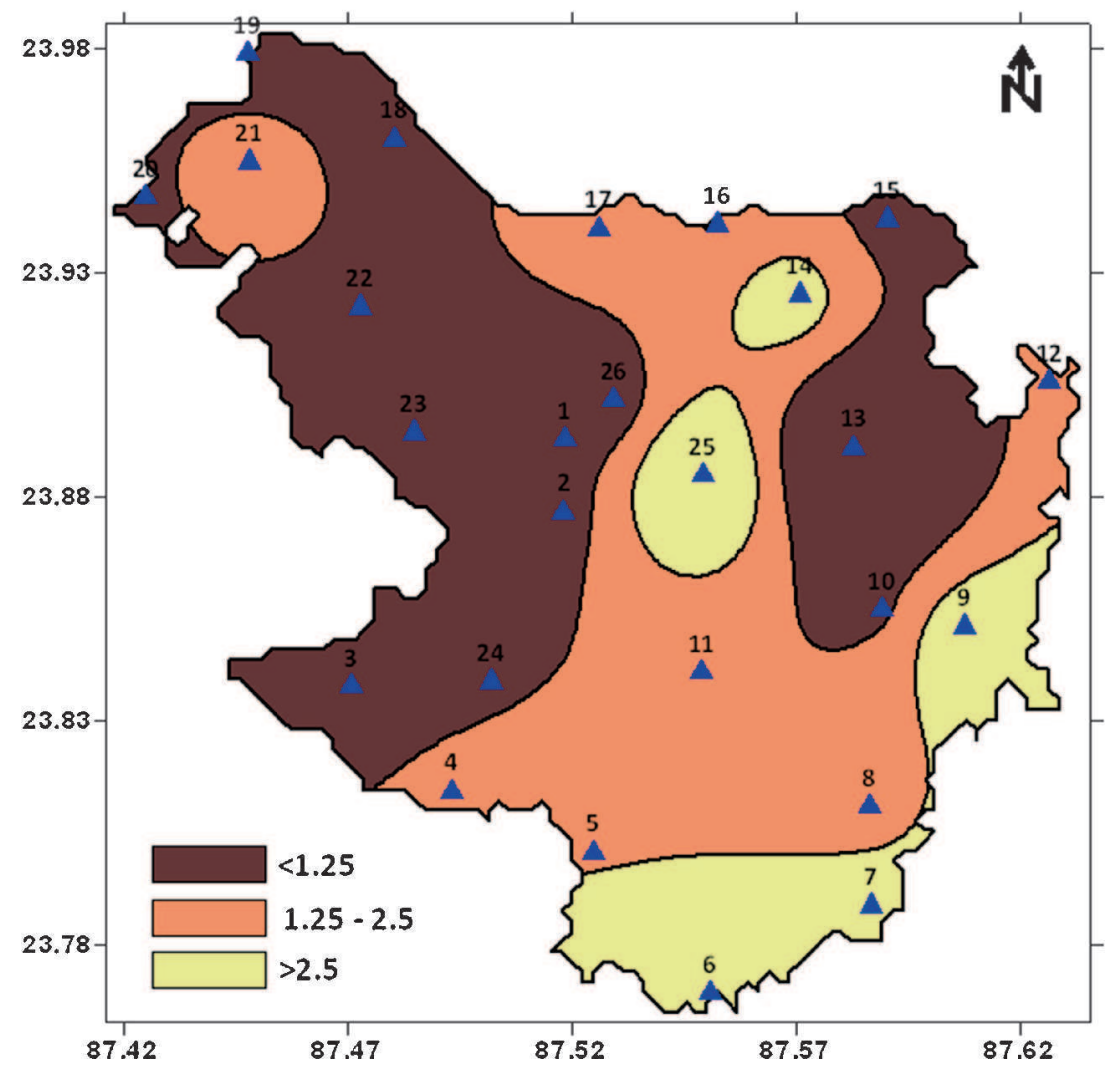

(b)

Figure 16. Spatial distribution of RSC (a) post-monsoon and (b) pre-monsoon. 


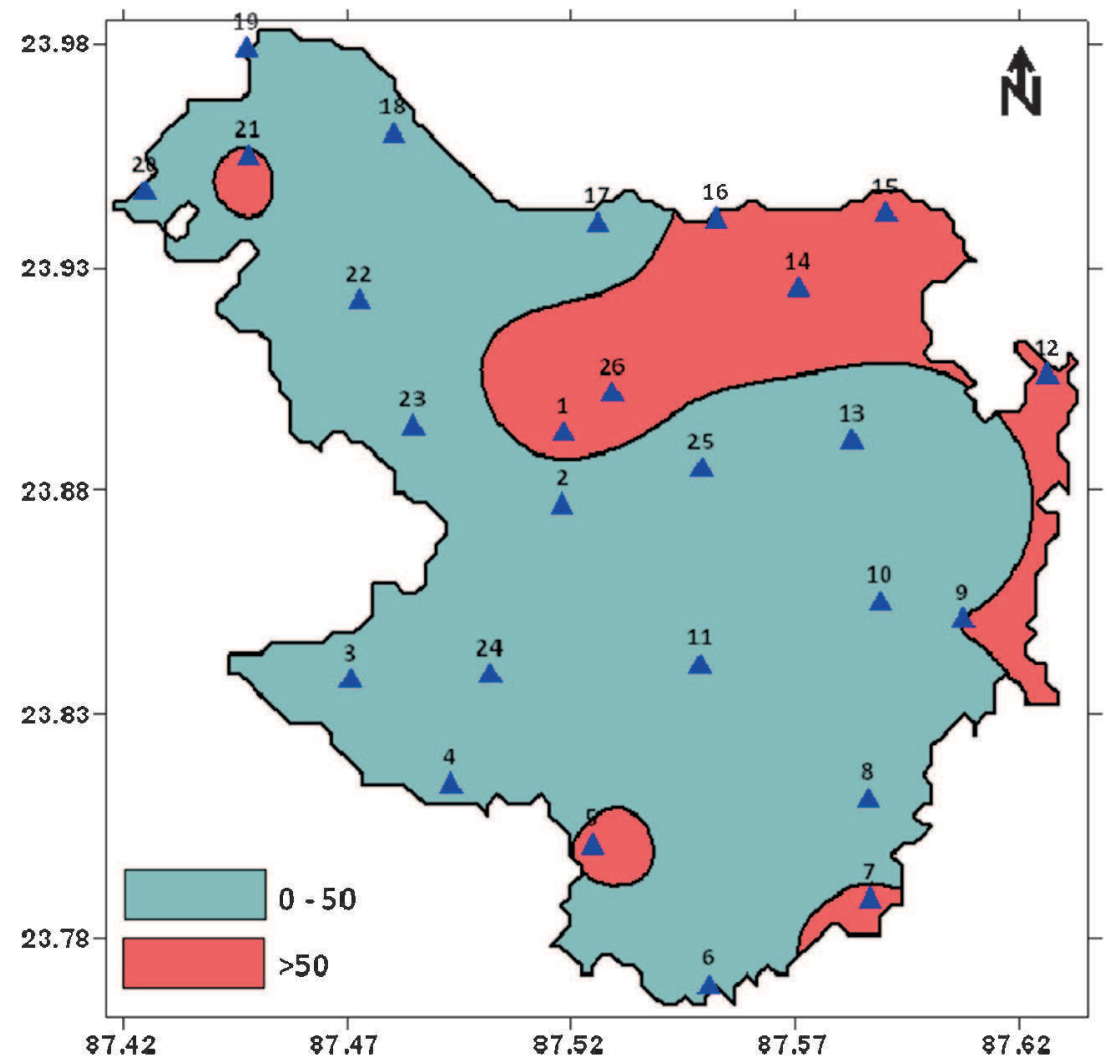

(a)

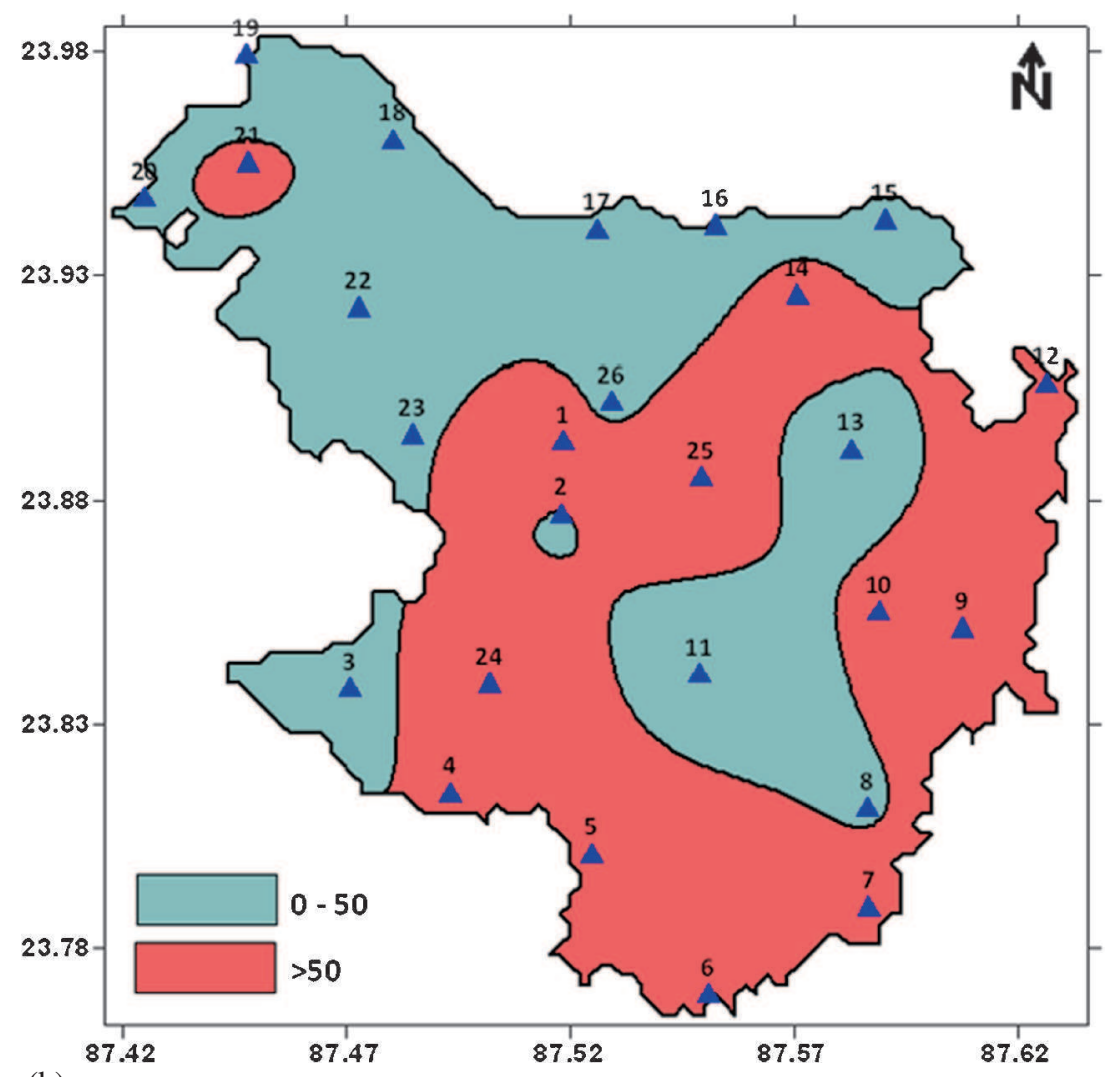

(b)

Figure 17. Spatial distribution of MAR (a) post-monsoon and (b) pre-monsoon. 


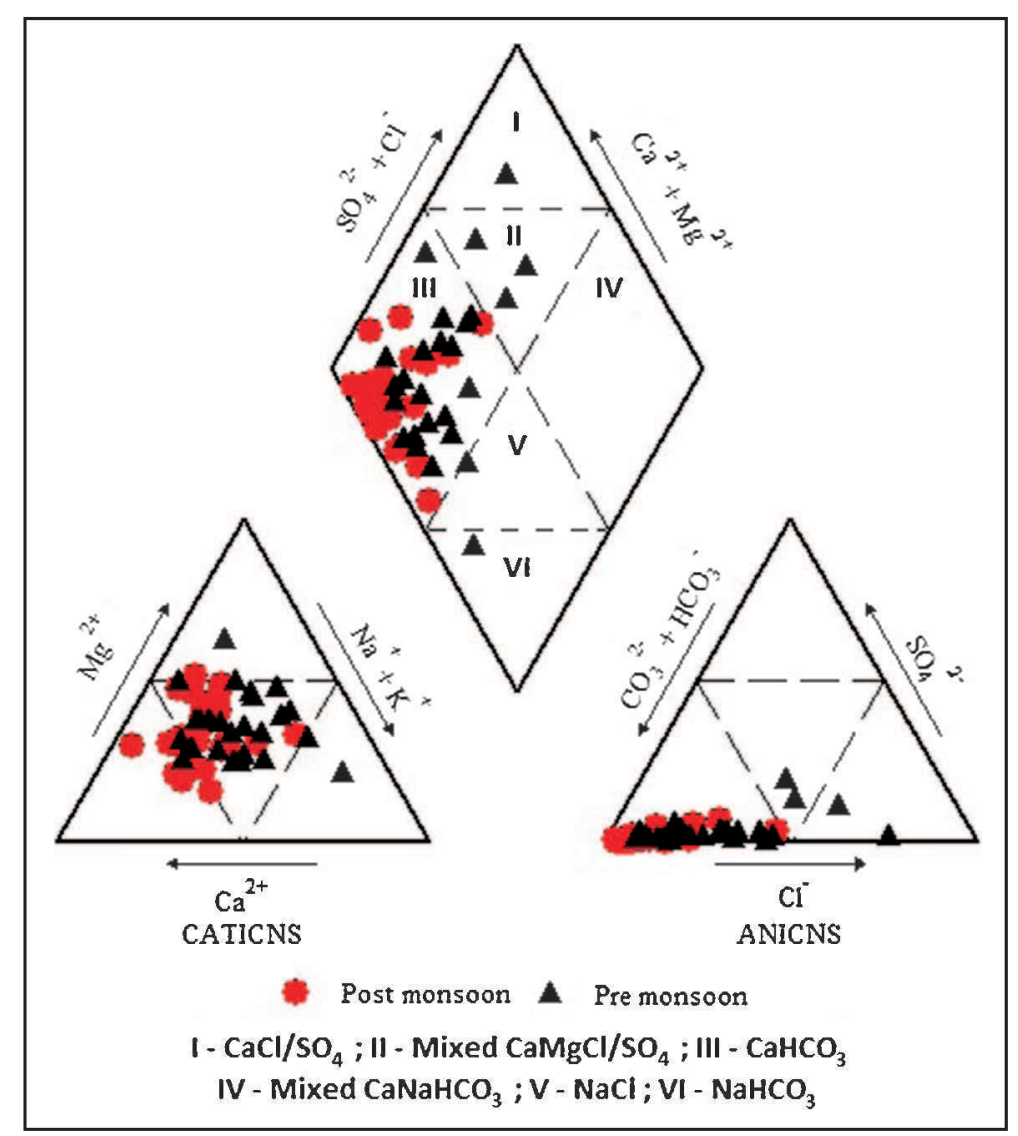

Figure 18. Piper trilinear diagram (post- and pre-monsoon).

boiled. Permanent hardness is caused by the presence of $\mathrm{Ca}^{2+}$ and $\mathrm{Mg}^{2+}$ which gets removed by ion exchange processes. Hardness of water limits its use for industrial purposes; causing scaling of pots, boilers and irrigation pipes, may cause health problems to humans, such as kidney failure (WHO 2008). The total hardness in $\mathrm{mg} / \mathrm{L}$ is determined by the following equation (Todd 1980).

$$
\mathrm{TH}(\mathrm{mg} / \mathrm{L})=2: 497 \mathrm{Ca}^{2+}+4: 115 \mathrm{Mg}^{2+}
$$

During post-monsoon, total hardness $(\mathrm{TH})$ ranges between 55.0 and $365.0 \mathrm{mg} / \mathrm{L}$ with an average of $206.9 \mathrm{mg} / \mathrm{L}$, and during pre-monsoon, it ranges between 48.0 and $384.0 \mathrm{mg} / \mathrm{L}$ with an average of $148.3 \mathrm{mg} / \mathrm{L}$. Covering the two sampling sessions, most of the water samples were found to be moderately hard in nature with exceptions of a few hard to very hard types as well.

\subsection{Hydrogeochemical facies}

Piper trilinear diagram is a graphical representation classifying water, based on the dominant presence of cations and anions and has widespread use to assess the water type (Back 1966; Apambire et al. 1997; Kumar et al. 2007). Piper diagram indicates suitability of drinking water based on the 'type' of water sample in accordance with the classification standards. Piper diagram broadly classifies water into four types: Bicarbonate type (fresh), sulfate type (which renders an odour to water) chloride or saline type (which renders a salty taste to water) (figure 18). In figure 18, it can be seen that the water samples fall under $\mathrm{CaMgHCO}_{3}$ or $\mathrm{NaHCO}_{3}$ (the bicarbonate type) during both postmonsoon and pre-monsoon sampling sessions. During pre-monsoon, a couple of samples fall under the $\mathrm{CaMgSO}_{4}$ and $\mathrm{CaMgClSO}_{4}$ (sulfate type) class as well.

\subsection{Water quality index (WQI)}

The contamination status of groundwater and whether or not it is suitable for consumption can be determined with the help of a quality index measure (Tiwari and Mishra 1985). For evaluation of WQI, the analyzed, standard and permissible values of ions present in water have been considered to calculate the quality rating of a water sample (Pradhan et al. 2001; Asadi et al. 2007).

$$
\mathrm{WQI}=\operatorname{Antilog}\left[W_{n=1}^{n} \log _{10} q_{n}\right]
$$




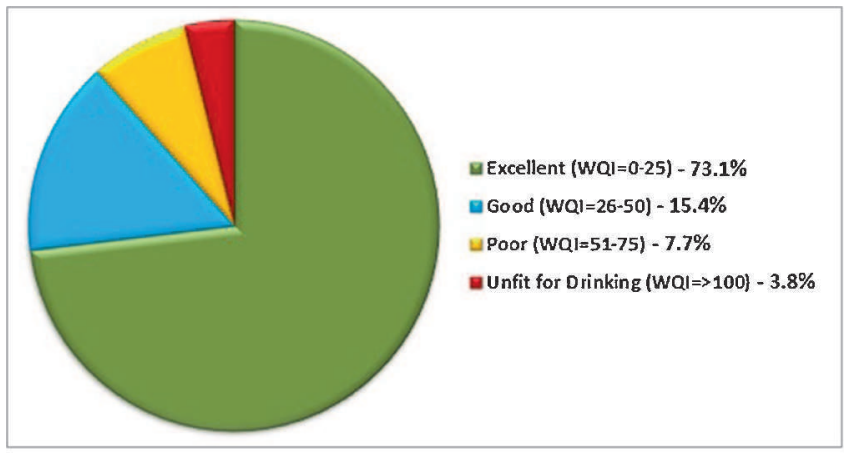

(a)

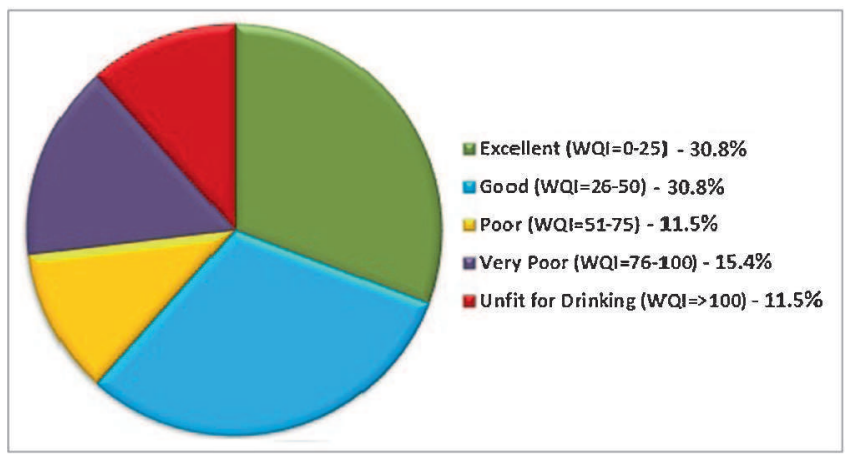

(b)

Figure 19. Categorization of groundwater according to WQI (a) post-monsoon and (b) pre-monsoon.

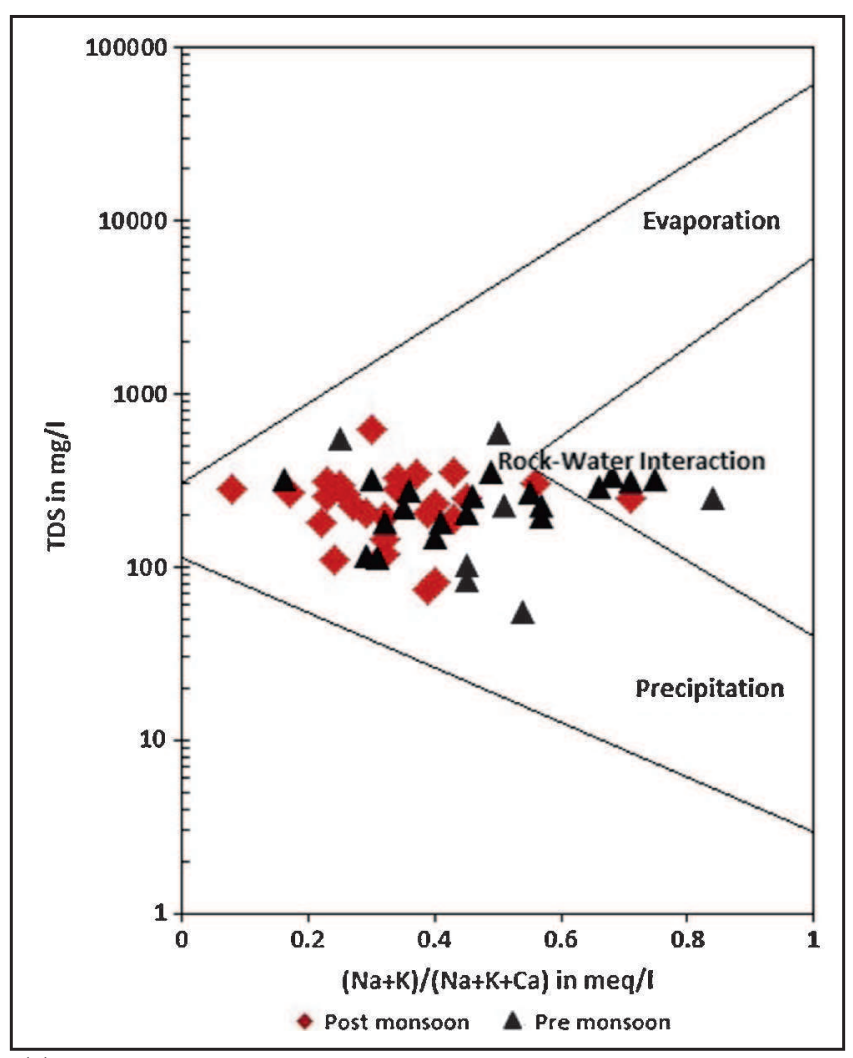

(a) where $W$ is weightage factor and $q$ is quality rating.

$$
W_{n}=K / S_{n}
$$

where the proportionality constant,

$$
K=\left[1 /\left(\sum_{n=1}^{n} 1 / S_{i}\right)\right]
$$

where $S_{n}$ and $S_{i}$ are the standard/permissible values of water quality parameters, proposed by WHO or ICMR.

Quality rating,

$q=\left\{\left[\left(V_{\text {actual }}-V_{\text {ideal }}\right) /\left(V_{\text {standard }}-V_{\text {ideal }}\right)\right] * 100\right\}$

where $V_{\text {actual }}=$ analytical value of $i$ th parameter obtained from laboratory analysis, $V_{\text {standard }}=\mathrm{WHO} /$ ICMR standard of $i$ th parameter and $V_{\text {ideal }}=$ value of $i$ th parameter obtained from standard tables ( $V_{\text {ideal }}=0$ for all parameters except $\mathrm{pH}$ for which $\left.V_{\text {ideal }}=7\right)$.

In table 3 , the classification ranges with respect to water quality index values of the water samples analyzed have been presented. Based on the standard, permissible and actual concentrations of each chemical parameter were tested and we reached the WQI value. Lower the WQI values,

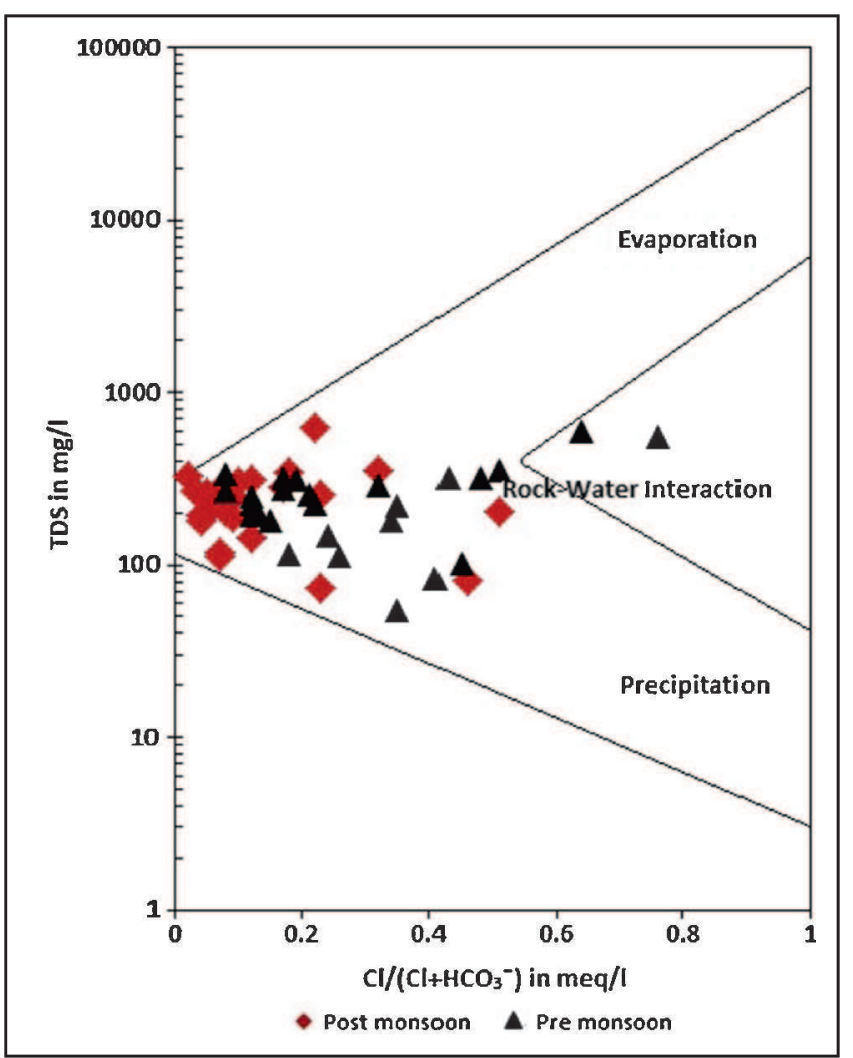

(b)

Figure 20. Gibbs' diagrams for post- and pre-monsoon. 
greater is the suitability of water with respect to drinking purpose. Similarly, higher values of WQI indicate poorer quality of water in terms of drinking. It is self-explanatory that water quality depends upon water quality index. Figure 19(a and b) shows pie diagrams which present the distribution of water samples for the post-monsoon and pre-monsoon sessions respectively with respect to the classification standards of water quality index study. Percentage of samples falling in each class of WQI study has been presented as individual sections of the pie diagram.

\subsection{Factors controlling hydrogeochemistry}

Gibbs' diagrams. The hydrogeochemistry of a particular region is usually determined by a number of factors like climate (average temperature of the region), geology (composition of the underlying bed rocks lining the aquifer systems in the region), rainfall, etc. Plotting of values of specific water quality parameters over the Gibbs' diagram (Gibbs 1970) gives us an insight as to which particular factor - evaporation, precipitation or rock-water interaction, plays the dominant role in controlling the hydrogeochemistry of an area. Gibbs' diagram is prepared using TDS, sodium $\left(\mathrm{Na}^{+}\right)$, potassium $\left(\mathrm{K}^{+}\right)$, calcium $\left(\mathrm{Ca}^{2+}\right)$, chloride $\left(\mathrm{Cl}^{-}\right)$and bicarbonate $\left(\mathrm{HCO}_{3}^{-}\right)$concentrations in groundwater. In figure 20(a and b), the Gibbs' diagrams for post-monsoon and pre-monsoon sessions have been presented. From these diagrams it can be interpreted that during both sampling sessions rockwater interaction processes significantly control the levels of all chemical constituents in groundwater of the study area. Dissolution and displacement reactions in rocks lining the aquifers are the primary reasons behind changing concentrations of major ions in solution.

\section{Conclusion}

The groundwater quality of Suri I and II blocks of Birbhum district, West Bengal has been assessed for its irrigational and domestic suitability purposes. The quantitative chemical analysis results reflect that the dominant cations in the study area are calcium and sodium and the dominant anions are bicarbonate and chloride. Hydrochemical facies analysis as well as the $\mathrm{pH}$ of water, both indicates that groundwater in the area is of alkaline nature. The electrical conductivity values and total dissolved solids values of water samples are all found to be within acceptable limits during both sampling sessions. Most of the water samples were found to be moderately hard in nature with exceptions of a few hard to very hard types as well.
Based on the water quality parameters analyzed like SAR, SSP, MAR, PI and KR, the suitability of groundwater samples for irrigation is good to medium in almost all cases, indicating low sodic waters, but may pose prominent alkaline hazard to soil reflected by the Residual Sodium Carbonate (RSC) values during post-monsoon. The groundwater will thus, neither cause salinity hazards nor have an adverse effect on the soil properties and is largely suitable for irrigational purposes. Piper diagram results show majority of samples belong to 'fresh water' type during both post- and pre-monsoon sessions. The water quality index results show that close to $90 \%$ of water samples are suitable for consumption during the post- monsoon session. $73.1 \%$ samples fall under the 'excellent' category and $15.4 \%$ samples fall under 'good' category during post-monsoon. During the pre-monsoon, a significant variation is noticed as only around $60 \%$ of the samples are found to be fit for drinking combining the 'excellent' (30.8\%) and 'good' (30.8\%) categories. Thus it can be concluded that overall quality of water with respect to drinking standards is better during the post-monsoon session in comparison with pre-monsoon.

Results from the water analysis were used as a tool to identify the process and mechanisms affecting the chemistry of groundwater from the study area. The data points of the area are plotted on the Gibbs' (1970) diagram. The plot is used to determine the mechanism controlling the water chemistry (figure 20a, b). The samples fall in rock-water interaction dominant zone indicating chemical weathering of rock-forming minerals as the prime factor influencing the groundwater quality suggesting dissolution and displacement of minerals constituting the aquifer materials.

\section{Acknowledgements}

The first author (S Das) is thankful to UGC, New Delhi and Jadavpur University, for providing her the UGC Research Fellowship in Science for Meritorious Student 2012-2013. The second author (S K Nag) gratefully acknowledges the financial support received from the UGC Major Research Project [F.No.41-1045/2012(SR)] in conducting the field work and analysis of the water samples. The authors gratefully acknowledge the support received from Dr S Gupta in analysing the parameters of water quality.

\section{References}

Aghazadeh N and Mogaddam A A 2010 Assessment of groundwater quality and its suitability for drinking and agricultural uses in the Oshnavieh area, northwest of Iran; J. Environ. Prot. 1 30-40. 
Al-Futaisi A, Rajmohan N and Al-Touqi S 2007 Groundwater quality monitoring in and around Barka dumping site, Sultanate of Oman; The Second IASTED (The International Association of Science and Technology for Development) International Conference on Water Resources Management (WRM 2007), Honolulu, Hawaii, USA, 2022 August.

Apambire W B, Boyle D R and Michael F A 1997 Geochemistry, genesis, and health implications of fluoriferous groundwaters in the upper regions of Ghana; Environ. Geol. 33(1) 13-24.

APHA (American Public Health Association) 1995 Standard Methods for Examination of Water and Waste Water; American Public Health Association, American Water Works Association and Water Pollution Control Federation, Washington DC, USA.

Asadi J J, Vuppala P and Reddy M A 2007 Remote sensing and GIS techniques for evaluation of groundwater quality in Municipal Corporation of Hyderabad (Zone-V), India; Int. J. Environ. Res. Public Health 4(1) 45-52.

Back W 1966 Hydrochemical facies and groundwater flow pattern in northern part of Atlantic Coastal Plain; US Geol. Survey, Prof. Paper 498-A 42.

BIS: 10500: 2012 Bureau of Indian Standard (2012) Drinking Water Specification, Second Revision, Bureau of Indian Standards, Manak Bhawan, 9, Bahadur Shah Zafar Marg, New Delhi.

Chatterjee R, Goorab T and Paul S 2010 Groundwater quality assessment of Dhanbad district, Jharkhand, India; Bull. Eng. Geol. Environ. 69 137-141.

Dart F J 1974 The Hazard of Iron; Water and Pollution Control, Ottawa.

Doneen L D 1964 Water quality for agriculture; Department of Irrigation, University of California, Davis, 48p.

Gibbs R J 1970 Mechanisms controlling world's water chemistry; Science 170 1088-1090.

Giggenbach W F 1988 Geothermal solute equilibria, Derivation of $\mathrm{Na}-\mathrm{K}-\mathrm{Mg}-\mathrm{Ca}$ geoindicators; Geochim. Cosmochim. Acta 52(12) 2749-2765.

Gupta S K and Gupta I C 1987 Management of Saline Soils and Water; Oxford and IBH Publ. Co., New Delhi, India, 399p.

Hem J D 1985 Study and interpretation of the chemical characteristics of natural water; $3 r d$ edn, Scientific Publishers, Jodhpur.

Huh Y, Tsoi M Y, Zaitiser A and Edwards J N 1998 The fluvial geochemistry of the river of eastern Siberia. I. Tributaries of Lena River draining the sedimentation platform of the Siberia Craton; Geochim. Cosmochim. Acta 62 1657-1676.

Ishaku J M, Ahmed A S and Abubakar M A 2011 Assessment of groundwater quality using chemical indices and GIS mapping in Jada area, Northeastern Nigeria; J. Earth Sci. Geotech. Eng. 1(1) 35-60.

Jalali M 2007 Hydrochemical identification of groundwater resources and their changes under the impacts of human activity in the Chah basin in western Iran; Environ. Monit. Assess 130 347-364.

Kelly W P 1963 Use of saline irrigation water; Soil Science 95(4) 355-391.

Khodapanah L, Sulaiman W N A and Khodapanah N 2009 Groundwater quality assessment for different purposes in Eshtehard District, Tehran, Iran; European J. Sci. Res. 36(4) 543-553.

Kumar M, Kumari K, Ramanathan A L and Saxena R 2007 A comparative evaluation of groundwater suitability for irrigation and drinking purposes in two intensively cultivated districts of Punjab, India; Environ. Geol. 53 $553-574$.
Milovanovic M 2007 Water quality assessment and determination of pollution sources along the Axios/Vardar River, southeast Europe; Desalination 213 159-173.

Moore C V 1973 Iron; In: Modern nutrition in health and disease; Lea and Febiger, Philadelphia, 297p.

Nag S K 2014 Evaluation of hydrochemical parameters and quality assessment of the groundwater in Gangajalghati Block, Bankura District, West Bengal, India; Arabian J. Sci. Eng. 39 5715-5727, doi: 10.1007/s13369-0141141-4.

Nag S K and Ghosh P 2013 Variation in groundwater levels and water quality in Chhatna Block, Bankura District, West Bengal - A GIS approach; J. Geol. Soc. India 81(2) 261-280.

Obiefuna G I and Sheriff A 2011 Assessment of shallow ground water quality of Pindiga Gombe Area, Yola Area, NE, Nigeria for irrigation and domestic purposes; Res. J. Environ. Earth Sci. 3(2) 131-141.

Paliwal K V 1972 Irrigation with saline water; Monogram no. 2 (New series), New Delhi, IARI, 198p.

Piper A M 1944 A graphical procedure in the geochemical interpretation of water analysis; Trans. Am. Geophys. Union 25 914-928.

Piper A M 1953 A graphic procedure in the geochemical interpretation of water analysis; USGS Ground Water Note 1263.

Pradhan S K, Patnaik D and Rout S P 2001 Water quality index for the groundwater in and around a phosphatic fertilizer plant; Indian J. Environ. Protect 21 355-358.

Pritchard M, Mkandawire T and O'Neill J G 2008 Assessment of groundwater quality in shallow wells within the southern districts of Malawi; Phys. Chem. Earth 3 812823.

Raghunath I I M 1987 Groundwater; 2nd edn; Wiley Eastern Ltd., New Delhi, India, pp. 344-369.

Ramesh K and Elango L 2012 Groundwater quality and its suitability for domestic and agricultural use in Tondiar river basin, Tamil Nadu, India; Environ. Monit. Assess. 184(6) 3887-3899.

Richards L A 1954 Diagnosis and Improvement of Saline and Alkali Soils; Agric Handbook 60. USDA and IBH Publ. Coy Ltd., New Delhi, India, pp. 98-99.

Rivers C N, Hiscock K M, Feast N A, Barrett M H and Dennis P F 1996 Use of nitrogen isotopes to identify nitrogen contamination of the Sherwood sandstone aquifer beneath the city of Nottingham, UK; Hydrol. J. 4(1) 90-102.

Sawyer G N and McCarty D L 1967 Chemistry of sanitary engineers; 2nd edn; McGraw Hill, New York, 518p.

Schiavo M A, Havser S, Gusimano G and Gatto L 2006 Geochemical characterization of groundwater and submarine discharge in the southeastern Sicily; Cont. Shelf Res. 26(7) 826-834.

Sharma H D and Chawla A S 1977 Manual on Ground Water and Tube Wells; Technical Report 18, Central Board of Irrigation and Power.

Sreedevi P D 2004 Groundwater quality of Pageru river basin, Cuddapah district, Andhra Pradesh; J. Geol. Soc. India 64 619-636.

Srinivasamoorthy K, Chidambaram S and Vasanthavigar M 2008 Geochemistry of fluorides in groundwater: Salem District, Tamil Nadu, India; J. Environ. Hydrol. 1 16-25.

Subramani T, Elango L and Dhamodarasamy S R 2005 Groundwater quality and its suitability for drinking and agricultural use in Chithar River Basin, Tamil Nadu, India; Environ. Geol. 47 1099-1110.

Tiwari T N and Mishra M 1985 A preliminary assignment of water quality index of major Indian rivers; Indian J. Environ. Protect. 5(4) 276-279. 
Todd D K 1980 Ground Water Hydrogeology; Wiley International Edition, John Wiley and Sons, Inc., New York.

UNESCO 2007 Water portal newsletter no. 161: Water related diseases; http://www.unesco.org/water/news/ newsletter/161.shtml.

US Salinity Lab 1954 Saline and Alkali Soils - Diagnosis and Improvement of US Salinity Laboratory; Agriculture Hand Book No. 60, Washington.

Vasanthavigar M, Srinivasamoorthy K, Vijayaragavan K, Rajiv Ganthi R, Chidambaram S, Sarama V S, Anandhan P, Manivannan R and Vasudevan S 2010 Application of water quality index for groundwater quality assessment:
Thirumanimuttar Sub-basin, Tamil Nadu, India; Environ. Monit. Assess. 171(1-4) 595-609.

Wadie A S T and Abduljalil G A D S 2010 Assessment of hydrochemical quality of groundwater under some urban areas within Sana'a Secretariat; Ecletica quimica. www.SCIELO.BR/EQ. 35(1)77-84.

WHO 2008 Guidelines for drinking-water quality: Incorporating first and second addenda, Recommendations, 3rd edn, WHO Press, vol. 1, 668p.

Wilcox L V 1955 Classification and Use of Irrigation Waters, USDA, Circular 969, Washington DC. 